\title{
Major Project Risk Management: Reconciling Complexity During Delivery with the Inside View in Planning
}

\author{
Paul Chapman ${ }^{1 *}$ and Cuong Quang ${ }^{2}$
}

\begin{abstract}
Recent research on the origins of risk during the planning and delivery of major projects broadly addresses two root causes: (i) complexity at the planning phase and also during project delivery, and; (ii) 'the inside view' at the planning phase and the associated issues of strategic misrepresentation and cognitive biases such as optimism bias. This paper presents the results of a systematic review that finds a schism in the literature showing theoretical and empirical treatment of project delivery risk polarises into considering either the effect of complexity or the inside view; rarely are they considered jointly. This work discusses the implications for theory and practice and identifies Case Based Decision Theory and Bayesian modelling, both of which are outside view techniques, as having potential to reconcile complexity and the inside view and thus provide for their joint treatment.
\end{abstract}

\section{Keywords}

Risk management, major project, complexity, inside view

\footnotetext{
${ }^{1 *}$ Saïd Business School, University of Oxford, Oxford, UK, paul.chapman@sbs.ox.ac.uk (Corresponding Author)

${ }^{2}$ Endeavour Programme, Brisbane, Australia
} 


\section{Introduction}

'Major project' is an umbrella term for largescale, complex undertakings that aim to deliver transformational outcomes, often at a regional or national level (Infrastructure and Projects Authority, 2020; Institute for Government, 2020). Examples include the United Nations Development Programme for climate change and refugee displacement (Boyer and McKinnon, 2015), investment in social infrastructure to deliver educational benefits (NYC Office of the Mayor, et al., 2014) or health benefits (UK NAO, 2018) to a population, strategy implementation involving new product introduction (Avots, 1969), organisational restructuring (Rouse, 2005), ICTenabled change (Gothelf and Seiden, 2017; Markus and Benjamin, 1997), and a range of engineering and construction related activities such as new or upgraded production facilities (Miller and Lessard, 2001), building transport infrastructure (Cantarelli et al., 2010a; Priemus and van Wee, 2013) and developing military equipment (UK NAO, 2015). While we use the term 'major projects' to refer to this breadth of endeavours, it is acknowledged they also sail under a variety of flags including, "major programmes" (Gordon, 2017; National Audit Office, 2020), "big science" (Cramer, 2020) and "strategic change" (Johnson, 1992) and do so without consistency in a manner that parallels their smaller scale cousins where, "Sometimes the words project and programme are used interchangeably." (Pellegrinelli, 2011). It is the case however that "major project" is widely used as shorthand in academia and amongst the practitioner community for organisations engaged in the initiation and delivery of major projects, programmes and portfolios (Australian Government, 2020; Barnes and Wearne, 1993; Flyvbjerg, 2011; Jacoby, 2017; Major Projects Association, n.d; von Branconi and Loch, 2004).

To delimit this work, its focus lies on the delivery of major projects, where issues relating to delivery performance has given rise to an extensive body of research on risk management and a diverse taxonomy of project delivery risks, their causes and ameliorative actions. Here project delivery risk is taken as being, "the exposure of stakeholders to the consequences of variation in outcome"
(Bartlett, 2004) which for project delivery involves comparing the outturn performance of a project relative to the objectives set out in the final business case, against which the final decision was made to commit investment to the project (Pickrell 1989; Pellegrinelli et al., 2007). This approach to project delivery performance assessment has been described as the international standard, "followed by academics, governments, and national audit offices around the world." (Flyvbjerg et al., 2019, p. 410). The objectives specified in a final business case typically include the benefits / outcomes the project is expected to achieve, and a budget and a timescale for their delivery. Best practice delivery risk management is concerned with identifying key project delivery risk that affects parameters such as performance, scope, quality, technology, environment, safety, health, schedule and cost, and managing these risks to reduce the chance that project delivery fails to meet requirements (Avots, 1969; Irimia-Diéguez et al., 2014; US National Research Council, 2005).

Despite extensive study and management of project delivery risk, a number of empirical studies of project delivery risk show that major project delivery experiences cost and schedule overruns, and quality and benefits shortfalls (Flyvbjerg, 2014; Merrow, 1988; Miller and Lessard, 2001). This has prompted the invigoration of new 'nondeterministic' research into the root causes of project delivery risk that are foundational to the causal claims made in the taxonomical literature (Padalkar and Gopinath, 2016a). This new strand of project delivery risk research frequently attributes project risk to two main causes, which are:

Complexity manifesting during delivery of a project, where for example (Williams, 2005; Williams et al., 2012, Geraldi et al., 2011 and Maylor et al., 2013) argue that major project delivery is risky because of techno-structural and socio-political complexity, where such complexity is subjective (Maylor et al., 2013) and dynamic (Geraldi et al., 2011). Complexity may be external to the project, for example as a result of the unpredictable nature of political, societal and economic environments (Chapman, 2016) and also internal to the pro- 
ject in terms of managing the project (Daniel and Daniel, 2019) as well as the technical nature of the project itself (Miller and Lessard, 2001).

Systematic errors in estimates at the project planning stage as a result of the decisionmaking heuristics and biases ascribed to the 'inside view' (Flyvbjerg, 2006; 2013a; Kahneman and Lovallo, 1993; Lovallo and Kahneman, 2003) where the ex-ante estimate of the project's cost, duration and benefits is primarily developed based on an analysis of the specific project at hand. A fundamental issue that affects project delivery risk management in these estimates is the cognition of risk and uncertainty. Knight's influential perspective (LeRoy and Singell, 1987) is that risk possesses defined probabilities on possible outcomes, whereas uncertainty does not. Taking an inside view places a reliance on analysis and calculation of identifiable and measurable project delivery risk where, "An inside view forecast is generated by focusing on the case at hand, by considering the plan and the obstacles to its completion, by constructing scenarios of future progress, and by extrapolating current trends" (Kahneman and Lovallo, 1993). This, "has had the unfortunate effect of obscuring [the] inherent unknowability of the future" (Winch and Maytorena, 2011) when ex-ante decision making. The repost to this is the 'outside view', which in contrast, "essentially ignores the details of the case at hand, and involves no attempt at detailed forecasting of the future history of the project. Instead, it focuses on the statistics of a class of cases chosen to be similar in relevant respects to the present one" (Kahneman and Lovallo, 1993). In doing so the outside view seeks to determine an overall probability, i.e. a statistical distribution, of the overall project delivery uncertainty through analysing the performance of a 'reference class' of similar projects and in doing so pools the implications and impact of the range of risk and uncertainty resulting from the totality of possible eventualities to inform, "rationally held (Keynes 1973) perceptions of that future." (Winch and Maytorena, 2011).

As research into these two root causes of project delivery risk has advanced, a schism has emerged between their respective proponents to the extent that they can be viewed as separate schools of thought. To illustrate this division, Holweg and Maylor (2018, pp. 1369), 1370) use the term "predict and prevent" to summarise the "operations and supply chain management' approach they advocate for managing delivery risk in major projects through addressing complexity. They position this as an alternative to, "the traditional approach to managing major projects", they term as, "predict and provide", where delivery risk is managed through addressing the inside view at the planning stage by calculating and providing increased contingency, an approach Holweg and Maylor comment on as presenting, "a fatalistic view of major projects" that they consider, "is only partially helpful in as far as it does not lead to prevention". In contrast, Flyvbjerg, described as "the leading proponent of behavioural explanations" (Transport Xtra, 2018) commented, "It is not complexity and scope changes in themselves that are the main problem; it is how human beings misconceive of these phenomena. This is a profound and proven insight that behavioural science brings to capital investment planning. Until you understand it, you're unlikely to get such investments right, including cost estimates." (Flyvbjerg et al., 2018).

While the two schools of thought both address the same phenomenon, their assessment of root causes and the respective cures they each advocate as being holistic appear difficult to reconcile.

\section{Research Questions}

Given that each of these two main strands of research concerning major project delivery risk appear to have merit in terms of their theoretical standing and the implications for practice that derive from them, this research sought to both understand the status of research that concerns treating complexity and the inside view as joint root causes of risk to major 
projects, and to seek to establish what means exist to leverage research insights and employ them to inform practice. This led to two research questions being posed, as follows:

1. "What is the available research that treats complexity and the inside view as joint root causes of project delivery risk for major projects?"

2. "What can be used to treat complexity and the inside view as joint root causes of project delivery risk in major projects?"

The next section describes the research methods used to investigate the two research questions. It explains the use of an exploratory literature review that combines systematic review, textual analysis techniques and conventional narrative review methods. Following that, the results of the review are presented along with a discussion on whether the two research questions have been answered. The paper ends with a conclusion that highlights the implications for theory and managerial practise of current gaps in knowledge on complexity and the inside view as joint root causes of delivery risk for major projects.

\section{Method}

A literature review using systematic and narrative methods is an appropriate approach to understanding available knowledge (Maylor et al., 2015, p. 104), and was selected to address the two research questions. The systematic method was chosen to attenuate potential biases of narrative literature reviews which can, "frequently lack thoroughness, and in many cases are not undertaken as genuine pieces of investigatory science" (Tranfield et al., 2003, p. 207).

Citation analysis (Flis and van Eck, 2017; Krauskopf, 2018; Palmblad and van Eck, 2018) is used as these provide visualisations of the relationships between word co-occurrences and author citations and in doing so gain a broad overview of knowledge patterns.

\section{Systematic Literature Review Protocol}

The eight-step systematic literature review protocol used an abbreviated, evidenced-informed systematic review method adapted from Tranfield et al. (2003), Denyer and Tranfield (2009, p. 683) and Briner and Denyer (2012, p. 121) that provided repeatability, transparency, comprehensiveness and minimises bias, as summarised in Table 1.

\section{Scoping the Field}

The three overlapping topics covered in the literature review were project risk, project complexity and the inside view, as depicted in Figure 1. Project governance was also included as a theme since it shares concerns that are common to all these topics.

This systematic literature review sought to determine the availability of research that addresses project complexity and the inside view as joint, rather than independent root causes of project risk. The papers by Geraldi et al. (2011) and Flyvbjerg (2006) form an appropriate basis for the "scoping study" that assists the "identification of keywords and search terms" for the systematic literature review (Tranfield et al., 2003, p. 215) as both have project delivery risk as central concerns but address it from complexity and inside view perspectives respectively.

\section{Defining and Refining the Systematic Literature Review Protocol}

The second step was to define the objective of the systematic literature review, which was to understand the current state of knowledge on complexity and the inside view as root causes of project delivery risk. The third step involved defining the criteria for considering literature for the search. This was to include all research concerning portfolio, programme and project management for all sectors, scales and geographies. Interventions of interest included governance systems, practices, processes and tools at major project, portfolio, programme and project levels and their effect on major project, portfolio, programme and project performance. Cost, time, quality and benefits realisation performance were particular emphases.

Steps four to seven describe the search strategy, eligibility for inclusion and exclusion, and quality standards. A keyword search using the main 
Table 1 Systematic literature review protocol. Adapted from (Briner and Denyer, 2012, p. 121) and Denyer and Tranfield (2009, p. 683)

\begin{tabular}{|c|c|}
\hline Systematic literature review - Step & Response \\
\hline $\begin{array}{l}\text { 1) Background } \\
\text { Research questions }\end{array}$ & $\begin{array}{l}\text { 1. "What is the available research that treats complexity and the } \\
\text { inside view as joint root causes of project delivery risk for major proj- } \\
\text { ects?" } \\
\text { 2. "What can be used to treat complexity and the inside view as joint } \\
\text { root causes of project delivery risk in major projects?" }\end{array}$ \\
\hline $\begin{array}{l}\text { 2) Objectives Primary objectives of } \\
\text { systematic literature review }\end{array}$ & $\begin{array}{l}\text { - Survey extant causes, and especially root causes, of major project } \\
\text { delivery risk } \\
\text { - Survey work that treats project complexity as a cause, and espe- } \\
\text { cially a root cause, of major project delivery risk } \\
\text { - Survey work that treats the inside view as a cause, and especially a } \\
\text { root cause, of major project delivery risk } \\
\text { - Assess whether inside view and complexity researchers acknowl- } \\
\text { edge each other's work as root causes of major project delivery risk } \\
\text { - Identify any work that treats complexity and the inside view as } \\
\text { joint root causes of major project delivery risk, rather than as indepen- } \\
\text { dent causes } \\
\text { - Identify any research that offers a solution to complexity and the } \\
\text { inside view as joint root causes of major project delivery risk }\end{array}$ \\
\hline \multicolumn{2}{|l|}{ 3)Criteria for considering literature } \\
\hline a) Context & $\begin{array}{l}\text { Major projects, including those known by other terms such as portfolios, } \\
\text { programmes and projects }\end{array}$ \\
\hline b) Interventions & Project governance systems and tools \\
\hline c) Mechanisms & $\begin{array}{l}\text { Managerial understanding of project delivery risk; systems and tools for } \\
\text { project delivery risk mitigation }\end{array}$ \\
\hline d) Outcomes & Project delivery risk reduction \\
\hline $\begin{array}{l}\text { e) Type of study (qualitative/ } \\
\text { quantitative) }\end{array}$ & Qualitative (theories) and quantitative (case studies) \\
\hline \multicolumn{2}{|l|}{ 4) Search strategy } \\
\hline a) Databases & $\begin{array}{l}\text { Main search portals: Search Oxford Libraries Online; Google Scholar; Web } \\
\text { of Science } \\
\text { Peer reviewed literature: ABI/Inform Global; Directory of Open Access } \\
\text { Journals; Elsevier (CrossRef); IEEE (CrossRef); IEEE Journals \& } \\
\text { Magazines; Informa - Taylor \& Francis; International Bibliography; } \\
\text { MEDLINE/Pubmed (NLM); SAGE Journals; Sage Publications (CrossRef); } \\
\text { Science Citation Index Expanded (Web of Science); ScienceDirect Journals } \\
\text { (Elsevier); Scopus (Elsevier); Social Sciences Citation Index (Web of } \\
\text { Science); EBSCO Business Source Complete; Taylor \& Francis Collection; } \\
\text { Technology Resource Database; ProQuest } \\
\text { Books: ProQuest ebook central; Bodleian library; University of Western } \\
\text { Australia library } \\
\text { Conference proceedings. } \\
\text { Grey material: ProQuest Dissertations and Theses: Global; Social Sciences } \\
\text { Research Network }\end{array}$ \\
\hline
\end{tabular}


Table 1 Continued

\begin{tabular}{|l|l|}
\hline Systematic literature review - Step & Response \\
\hline b) Sources (indicative) & $\begin{array}{l}\text { International Journal of Project Management; Project Management Journal; } \\
\text { Transport Policy; Transport Reviews } \\
\text { International Journal of Business and Management; Production Planning \& } \\
\text { Control }\end{array}$ \\
\hline c) Time period & \begin{tabular}{l} 
1960-2019 \\
\hline "project risk" AND "inside view" \\
"project risk" AND "inside view" AND "project complexity" \\
"project risk" AND "project complexity" \\
"project risk" AND "project complexity" AND "project governance" \\
"project risk" AND "optimism bias" \\
"project risk" AND "optimism bias" AND "project complexity" \\
"project risk" AND "outside view" \\
"project risk" AND "outside view" AND "project complexity" \\
"project risk" AND "project governance" \\
"project risk" AND "root causes" \\
"project risk" AND "root causes" AND "inside view" \\
"project risk" AND "root causes" AND "project complexity"
\end{tabular} \\
\hline $\begin{array}{l}\text { d) Search terms and key words } \\
\text { 5) Eligibility }\end{array}$ & $\begin{array}{l}\text { Inclusion criteria: Papers written in English; Full text available } \\
\text { Inclusion criteria: requirement that the literature must address the research } \\
\text { question. } \\
\text { Inclusion criteria: requirement that for case-related or theoretical literature, } \\
\text { "project" must be mentioned in the title, keywords or abstract, or it must be } \\
\text { referred to within a paper on the topic. } \\
\text { Exclusion criteria: duplicates are removed }\end{array}$ \\
\hline 7) Data collection & $\begin{array}{l}\text { Literature data that will be collected: Number of search results returned; } \\
\text { journal results; topics; }\end{array}$ \\
\hline 8) Type of synthesis used & $\begin{array}{l}\text { Integration } \\
\text { Criteria used to assess quality: Peer-reviewed journals }\end{array}$ \\
\hline
\end{tabular}

"Search Oxford Online" search portal provided access to relevant databases for identifying an initial selection of documents. The search terms and keywords used are shown in Table 1.

After performing the keyword searches, the documents were filtered using the following exclusion and inclusion criteria: (i) papers must relate to major projects, portfolios, programmes or projects, (ii) they must address the research questions, and (iii) they must be from peerreviewed journals.

The focus for this research is on 'major projects', however these endeavours lack consensus on nomenclature and can be referred to by a variety of terms, such as 'major programmes'. As the keyword terms employed in the initial round of literature search uses "project", a snowball-sampled literature search was also performed on papers identified during the initial round in order to extend the search in order to identify and include relevant literature that employed alternative terminology. To maintain comprehensiveness of the systematic literature search, grey literature including unpublished dissertations and papers from the Social Sciences Research Network ("SSRN") are also kept for secondary analysis.

Finally, step eight involved identifying and implementing a synthesising framework. The specifics of the approach employed are described in the relevant section following. 


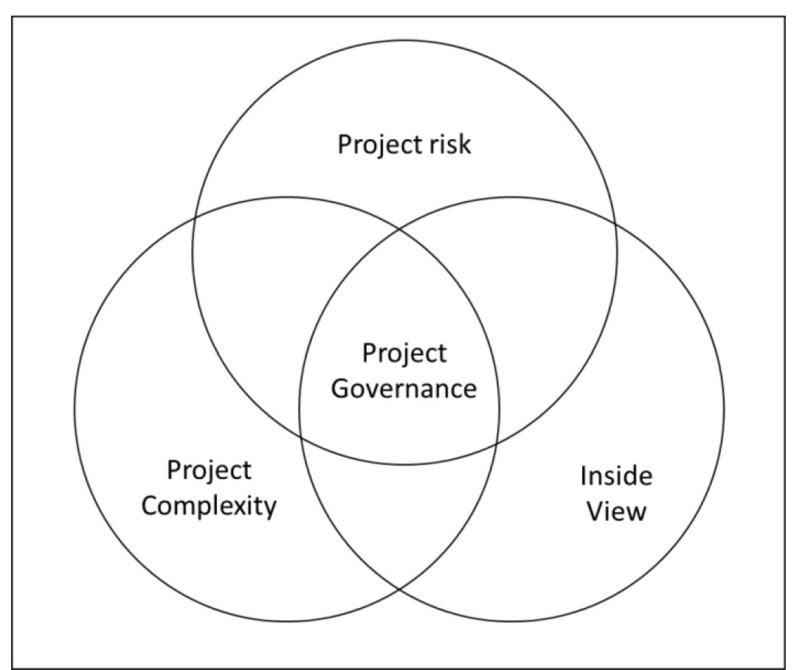

Figure 1 Conceptual overview of literature review.

\section{Literature Review Findings}

This section presents the results of the systematic literature review and a discussion of its findings. In doing so the findings are synthesised using an integration research synthesis method.

Figure 2 summarises the results of the systematic literature review and shows the number of journal papers identified through the database searches using the various search terms and keywords associated with project complexity and/ or the inside view as root causes of project delivery risk.

\section{Bibliographic Analysis}

In stage \#1, an initial series of article searches based on key word conjugations were conducted. The initial key word search on "project risk" returned 25126 results. Conjugating this with additional key word pairs and triplets shown in Figure 2 resulted in a final number of 196 documents across the range of key word combinations. From this initial search (excluding snowball search conducted later), project complexity or the inside view as root causes of project risk returned 87 results between them.

The inside view is a collective term for several cognitive biases including optimism bias. Despite this, optimism bias as a source of project risk was found to receive more attention in the literature with 119 results and there was comparatively greater recognition of its relationship with project complexity with 28 results returned.

In stage \#2, the inclusion/ exclusion criteria from Table 1 were applied to the search results

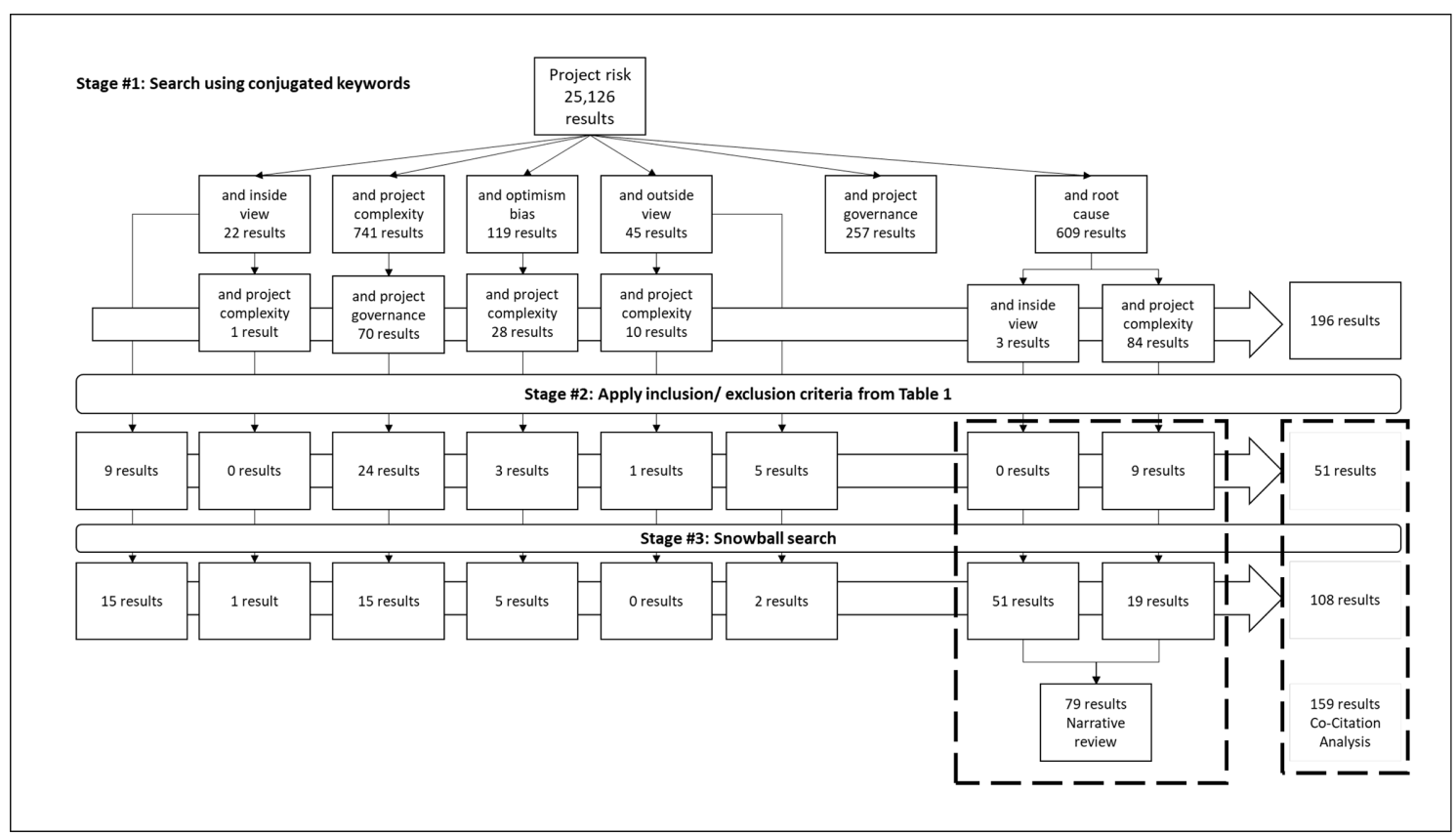

Figure 2 Search results on project complexity and/or the inside view as root causes of project delivery risk using systematic literature review and snowball search. 
reducing the initial 196 documents to 51. None of these 51 papers dealt with the inside view as a root cause of project risk whilst only nine of these papers dealt with project complexity as a root cause of project risk.

In stage \#3 a snowball search was conducted from these 51 papers which identified another 108 papers across all keyword combinations to produce a total of 159 documents. Since the focus of this current paper is on the inside view and project complexity as root causes of project delivery risk and the previous step produced so few documents, the snowball search prioritised these two topics. These 159 documents were used in the citation analysis to provide a broad overview of the field. Of the 108 papers produced in stage \#3, 70 papers dealt with the inside view or project complexity as a root cause of project risk (51 and 19 papers respectively).

In total there were a total of 79 papers (nine from stage \#2 and 70 from stage \#3) discussing the root causes of project risk in terms of the inside view or project complexity, or both simultaneously.

\section{Narrative Review}

The literature identified through the systematic literature review were synthesised using the integration research method. Rousseau et al. (2008, pp. 492-493) identify four forms of research synthesis, where the integration form of research synthesis proved to be the most appropriate as this facilitates investigation of questions relating to "cause-effect relationships" (Rousseau et al., 2008, p. 495). This integration synthesis method needed to qualitatively improve construct, internal and external validity (Rousseau et al., 2008, pp. 481-482) and satisfy the three criteria: (i) it must be able to synthesise knowledge across complexity and inside view research; (ii) it must deal with cause-effect relationships; and (iii) it must be related to projects. A number of synthesis frameworks from existing systematic reviews of complexity research were considered, such as those by (Bakhshi et al., 2016; Bosch-Rekveldt et al., 2011; Geraldi et al., 2011; Padalkar and Gopinath, 2016b; Thomé et al., 2016b). Likewise, integration frameworks for behavioural decisionmaking phenomena on projects from scholars such as Stingl and Geraldi (2017) were also reviewed. All of these have projects as their contextual focus however they synthesise knowledge within, but not across topics. Moreover, none directly addressed cause-effect relationships in the way the research questions require. In contrast, Flyvbjerg (2017, pp. 1-18) "challenges-causes-cures" framework proved highly suitable because it: (i) identifies cost and schedule overrun are recurrent problems in major project delivery performance; (ii) describes and evaluates several contributory technological, political and psychological causes for these problems, and (iii) prescribes solutions to these underlying causes that address the problems. For these reasons, Flyvbjerg (2007) "challengescauses-cures" framework was adopted as the integration framework for the research synthesis.

The integration synthesis of the 79 papers treating the inside view and/or complexity as root causes of project delivery risk highlighted three primary cause-effect relationships:

- Predict and Provide: Operational responses. Potential delivery risk is assessed during planning with contingency provided through pre-emptive investment in operational capability and/or by preplanning responses for when delivery risks manifest.

- Predict and Provide: Financial Responses. Potential delivery risk is assessed during planning at an overall level and responded to with an uplift in the project's budget, held as contingency.

- Predict and Prevent Responses. Potential delivery risk is assessed and anticipated at the planning stage and periodically during delivery with action taken to identify and pre-emptively mitigate delivery risks.

The papers summarised under these cause-effect relationships are arranged into Table 2 respectively, where Flyvbjerg's "Challenges-Causes-Cures" framework is employed to further synthesise the literature and draw out common themes. 


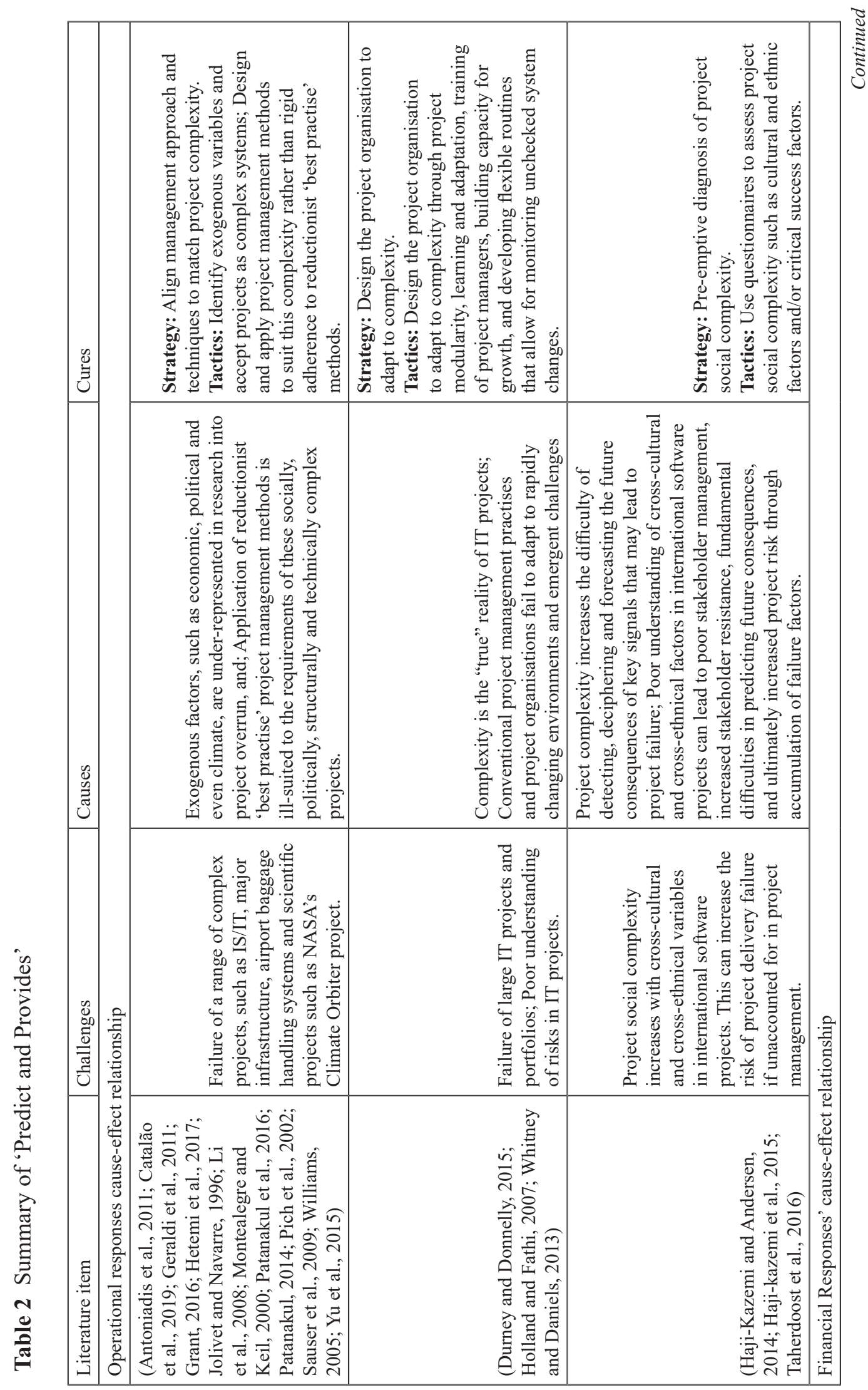

Engineering Project Organization Journal

(C) 2021 Engineering Project Organization Society www.epossociety.org 


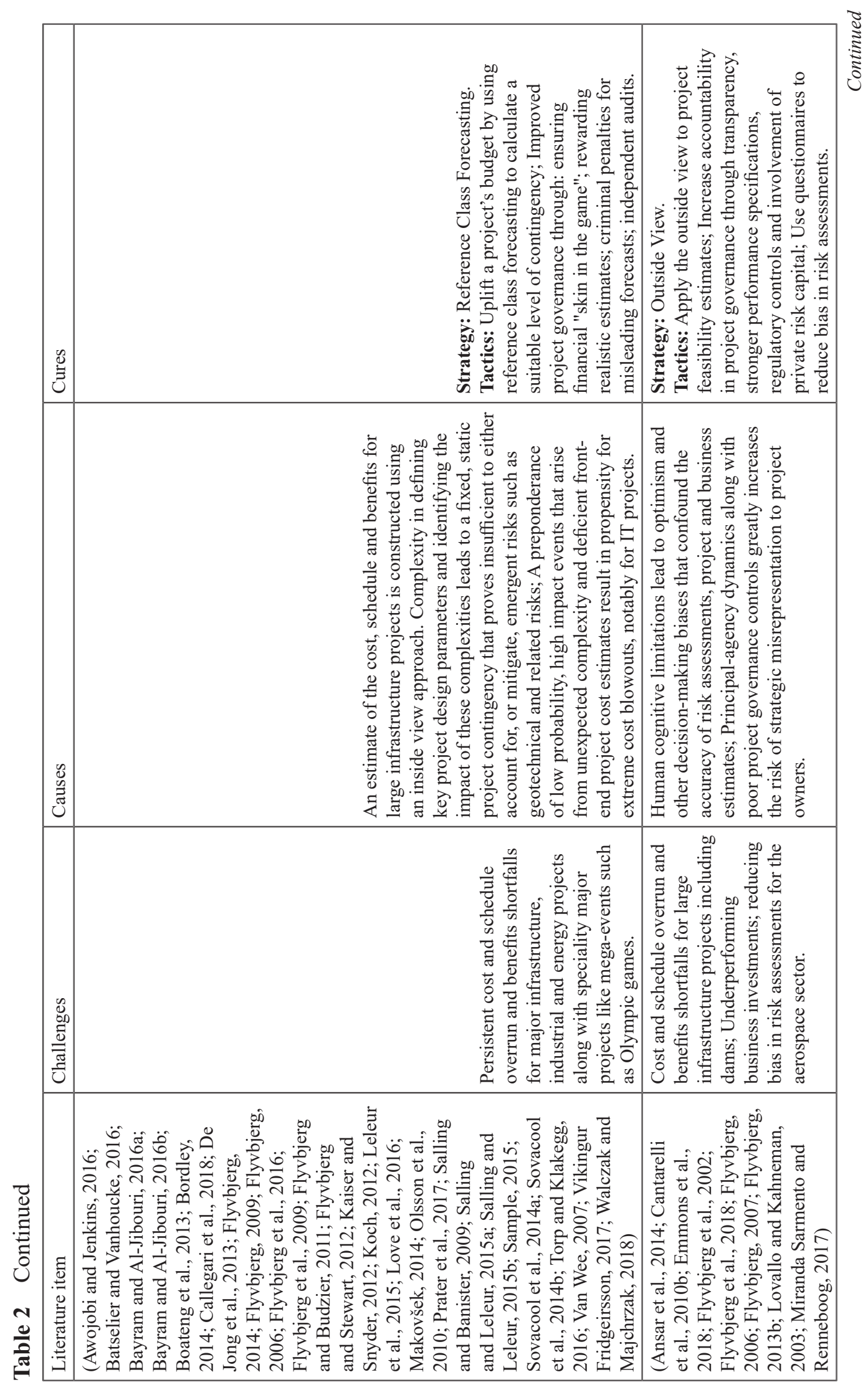

Engineering Project Organization Journal

(C) 2021 Engineering Project Organization Society www.epossociety.org 


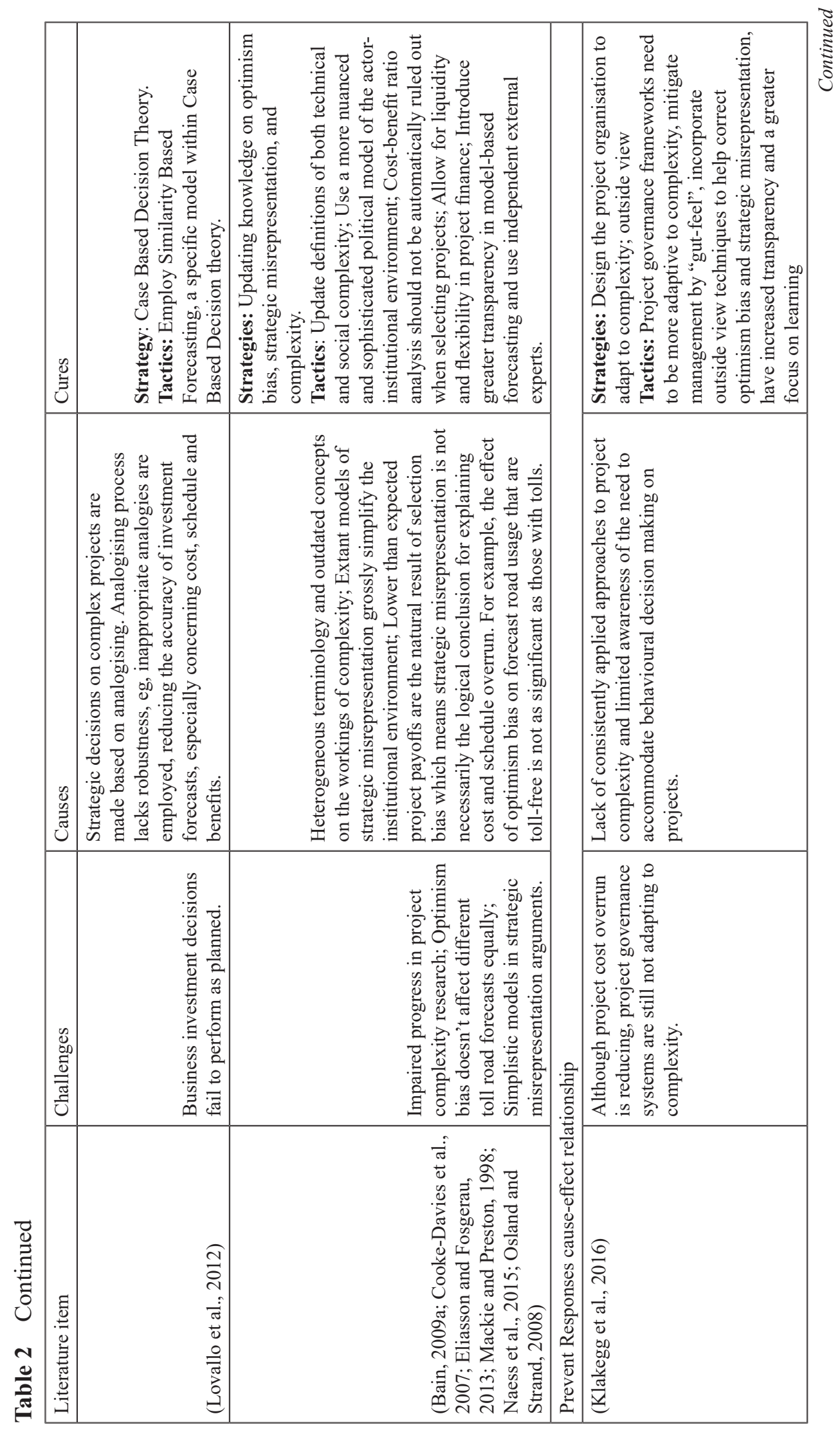

Engineering Project Organization Journal

(C) 2021 Engineering Project Organization Society www.epossociety.org 


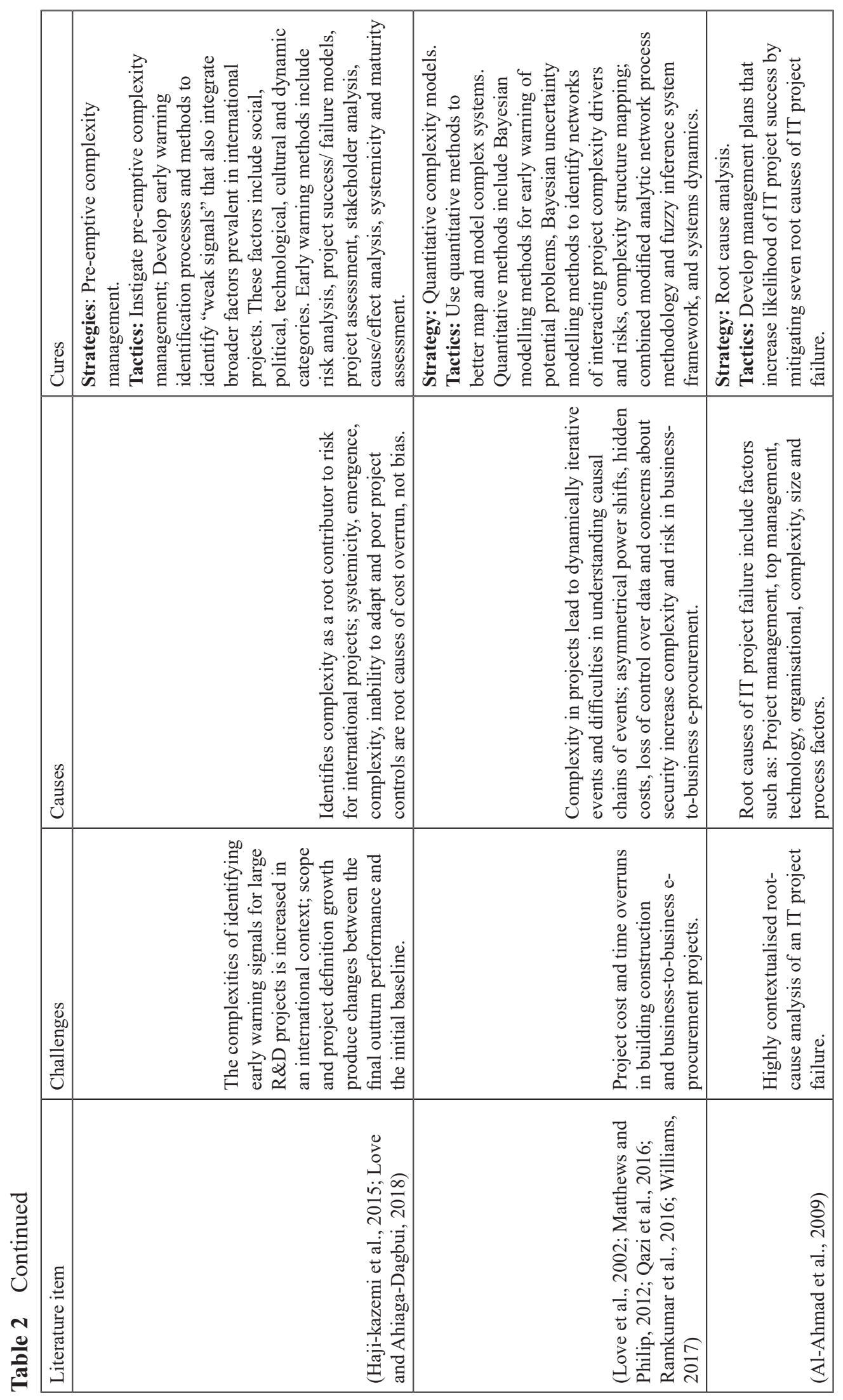

Engineering Project Organization Journal

(C) 2021 Engineering Project Organization Society www.epossociety.org 


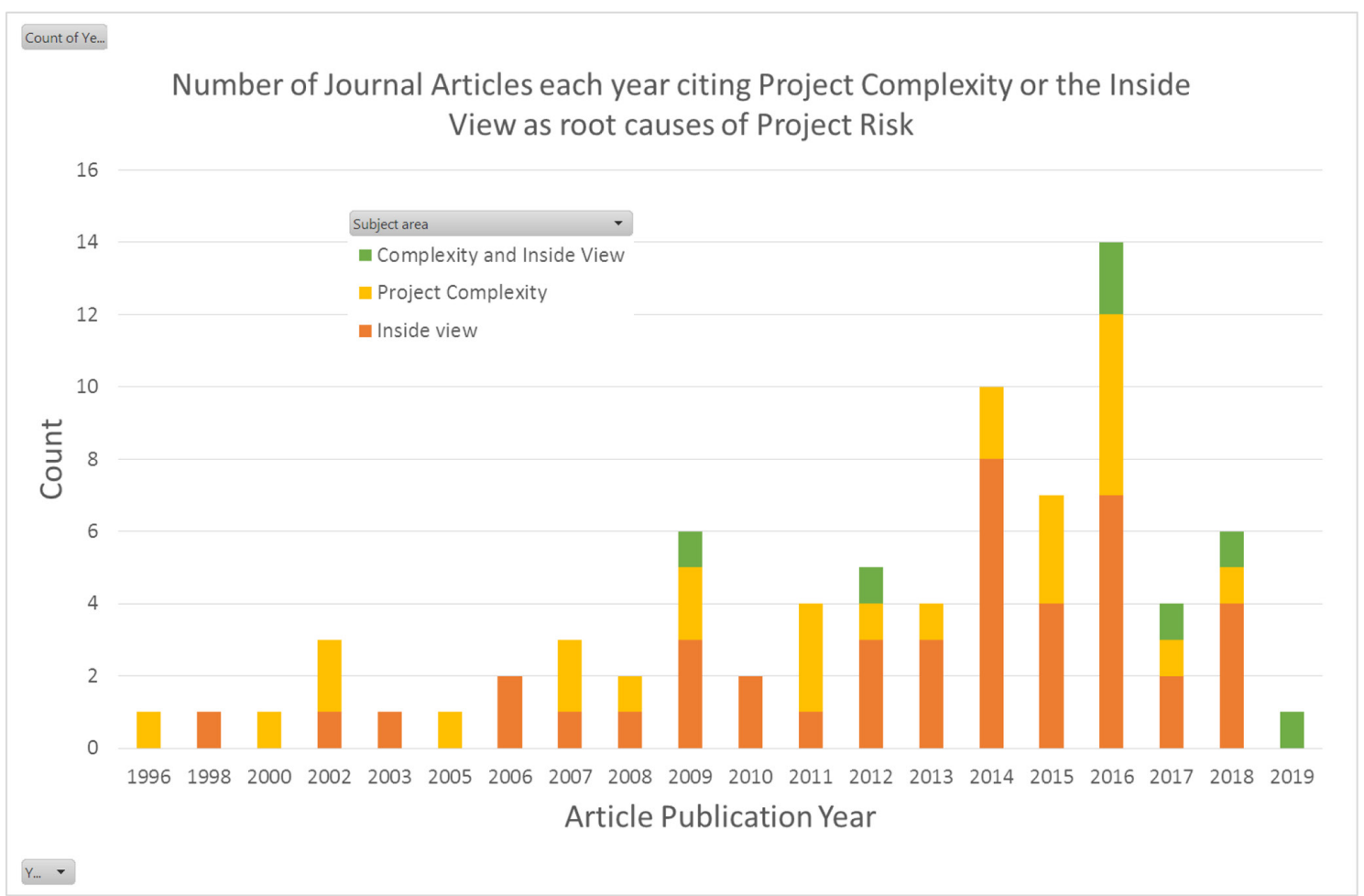

Figure 3 Number of journal articles published each year that cite project complexity or the inside view as root causes of project delivery risk.

\section{Analysis of the Literature}

The findings from the literature review were analysed using:

- Bibliographic analysis

- Citation analysis

These methods are outlined below.

\section{Bibliographic analysis}

An assessment was made of the corpus of literature uncovered by the review. This assessment adapted the procedure described by (Thomé et al., 2016b, pp. 414-418), to provide descriptive data on the various articles including: (i) publications by year; (ii) according to topic; (iii) by publication; and (iv) per type of study.

\section{Publications by year, by topic}

Figure 3 shows the chronological tally of papers that cite project complexity or the inside view as root causes of project delivery risk.
These findings show there is a substantial amount of literature available on project complexity, project governance, or root causes of project risk, as these have had a longer pedigree in project management research (25 126 documents total). However, there is comparatively little literature on project delivery risk combined with either the inside view or the outside view. There were relatively few results returned for either theoretical or empirical research that investigates both complexity and the inside view as joint root causes of delivery risk in contrast to the total project risk corpus though this has changed in recent years. For instance, De Rezende et al. (2018, p. 48) show that from 2014-2016 project complexity research has included more work on behavioural decision making processes in complex project environments

\section{Articles by publication}

Figure 4 identifies which publications were publishing articles on the inside view and project complexity as root causes of project risk. 


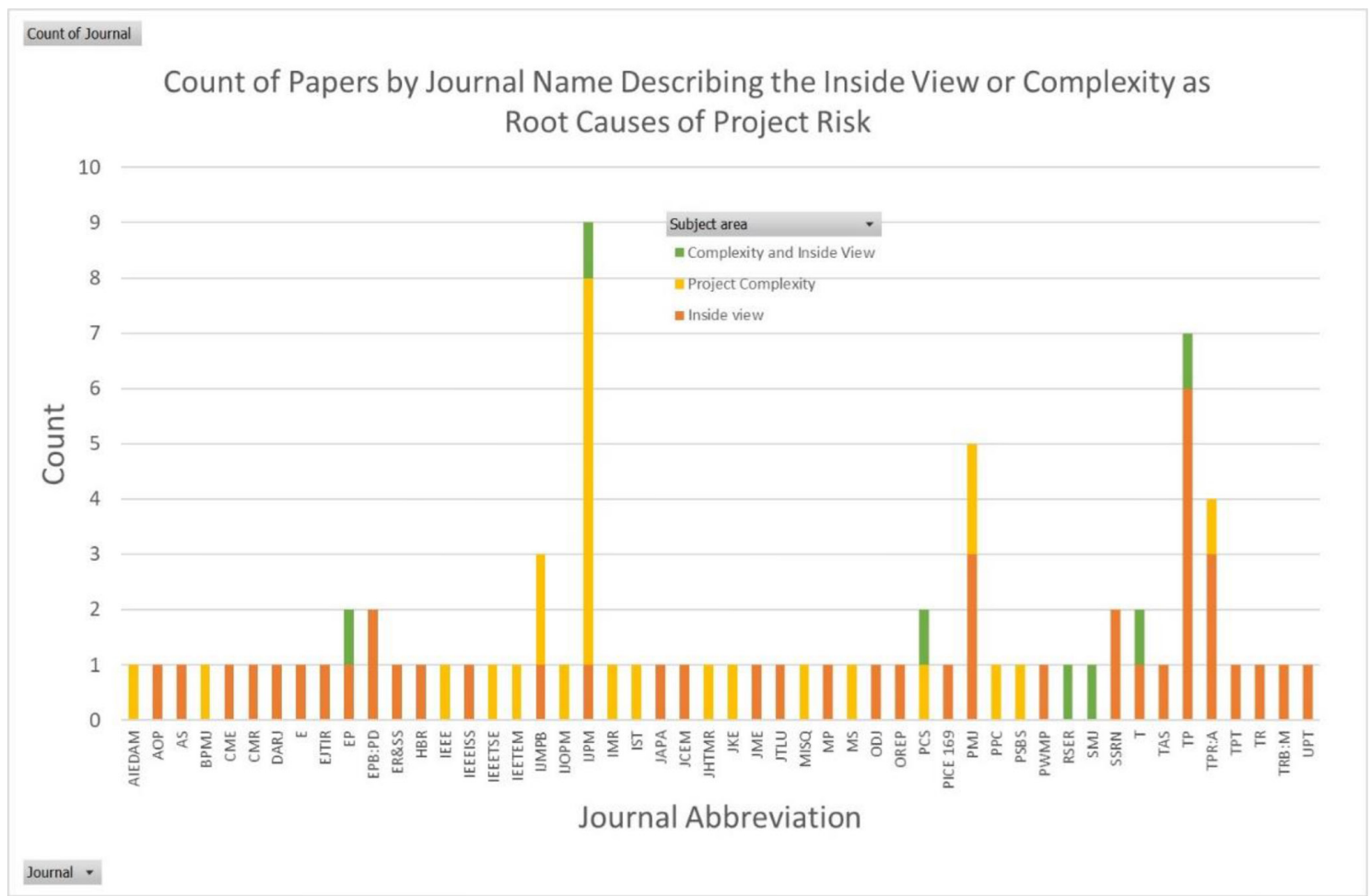

Figure 4 Histogram of journals publishing articles describing project complexity or the inside view as root causes of project delivery risk. See Appendix 1 for the list of journal titles for these abbreviations.

Figure 4 shows that International Journal of Project Management (IJPM), Project Management Journal (PMJ) and Transport Policy (TP) are key sources of relevant literature although papers are found across a breadth of other engineering, management science, business and economics journals. As root causes of project delivery risk, project complexity features most prominently in the project management journals while reference class forecasting appears most frequently in transportation and construction management journals.

\section{Articles by study type}

Figure 5 shows most of the research methodologies are case studies (53\%) and documentary research $(33 \%)$ while only $14 \%$ is experimental research. Case study research included both quantitative and qualitative work including literature review, interviews, documentary analysis, questionnaires and content analysis.

\section{Citation Analysis}

A citation analysis is a useful approach for working back from a set of relevant papers to achieve a broader understanding of available knowledge on a topic. Since the research sought to investigate the ways research on project complexity and the inside view interrelates, citation analysis was used to visually depict connections between documents and provide a useful way to quantify the extent of these relationships, where they exist (Artto et al., 2009; Biesenthal and Wilden, 2014; Thomé et al., 2016a, p. 1340)Thomé et al., 2016b, p. 409, 412, 417; Zheng et al., 2016). Bibliometric analysis software called Vosviewer was used to conduct the citation analysis and network visualisation (Jan and Waltman, 2018). Within Vosviewer, the citation map was created based on bibliographic data from Web of Science text files, using "citation" analysis on a "document" unit of analysis. Stranded papers with no citations (mostly from complexity research) were excluded from the resulting visualisation. 


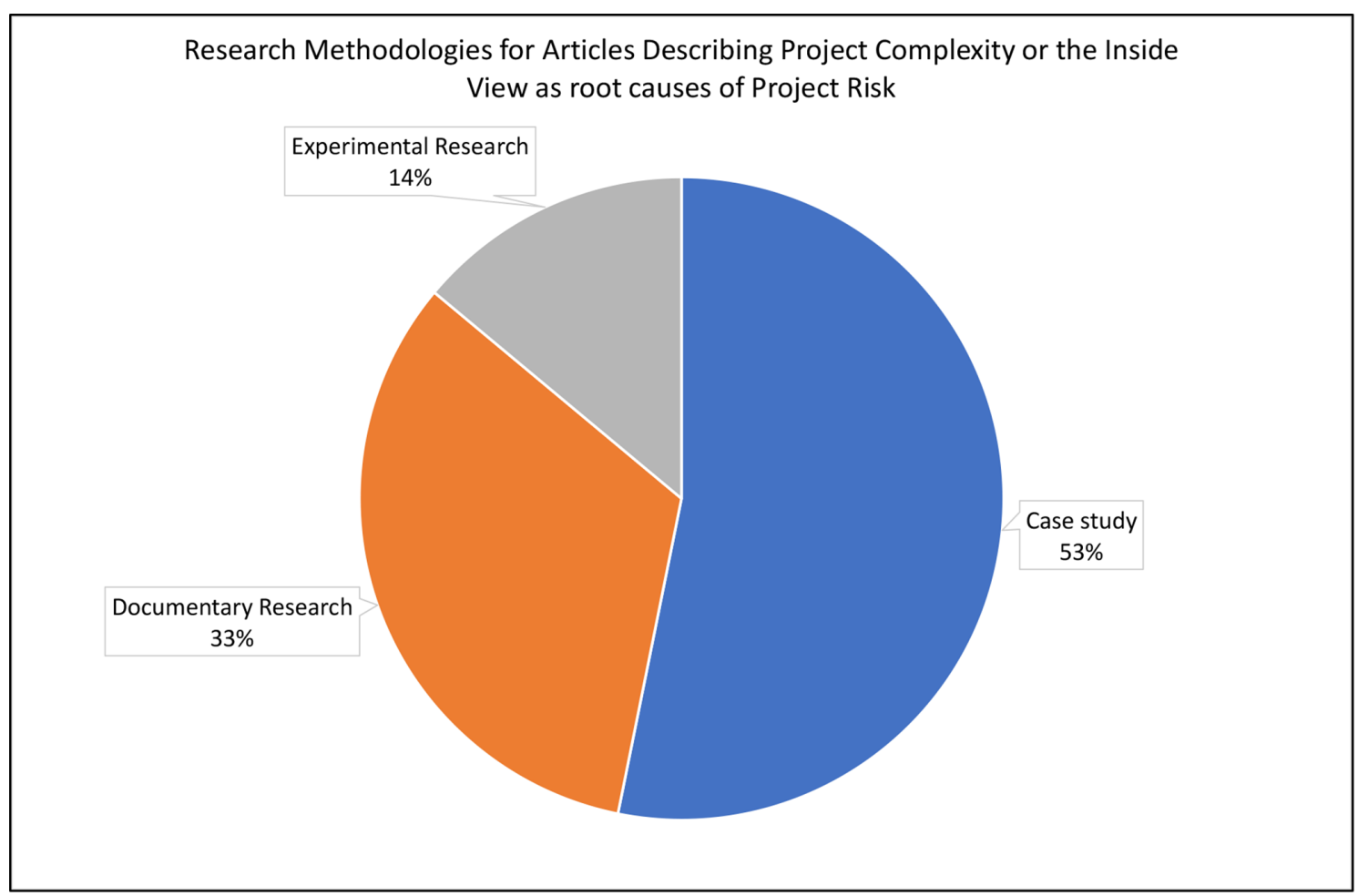

Figure 5 Research methodologies of journal articles describing project complexity or the inside view as root causes of project delivery risk. $\mathrm{N}=79$.

The search query conducted on Web of Science was: (i) "Topic $=$ complex" AND "Topic= project management" OR ("Author= Kahneman, D" OR "Author= Tversky, A" OR "Author= Lovallo, D" OR "Author= Flyvbjerg, B"); and (ii) delimiters in "Research Areas" were set to: "Business Economics" OR "Engineering" OR "Operations Research Management Science" OR "Computer Science" OR "Public Administration" OR "Transport" OR "Social Sciences Other Topics".

This citation analysis identified 1667 documents comprising 1514 project complexity articles and 153 inside view/ cognitive bias articles. A visual presentation of the findings from this analysis is shown in Figure 6.

Figure 6 shows the two major clusters for complexity and inside view research and the citation relationships between authors (including to earlier work by themselves). 'Cluster 1. Complexity' shows documents relating to project complexity and indicates six main sub-clusters concerning: (I) typologies, models, constructs and algorithms; (ii) stakeholders and risk; (iii) system dynamics effects; (iv) management information systems;
(V) organisational learning and professional education, and; (vi) sociological perspectives. 'Cluster 2. Inside View and Behavioural Decision Making' shows articles relating to the inside view / behavioural decision-making with four sub-clusters concerning: (I) megaprojects and governance; (ii) prospect theory and decision making under uncertainty; (iii) applications in economics, and; (iv) behavioural strategy. The intra-cluster citation relationships within the inside view cluster are thick, frequent and direct; the complexity cluster less so, suggesting the research is more fragmented. The inter-cluster citation relationships between Cluster one and Cluster two are very weak however by comparison, with very few citations between the inside view scholars (notably Flyvbjerg) and those researching complexity. The few complexity scholars citing work by the inside view scholars have only done so recently, for example (Awojobi and Jenkins, 2016; Bain, 2009b; Hetemi et al., 2017; Holweg and Maylor, 2018; Liu et al., 2014; Williams et al., 2012). This indicates that despite the increasing trend for project management research to address the behavioural dimensions of 


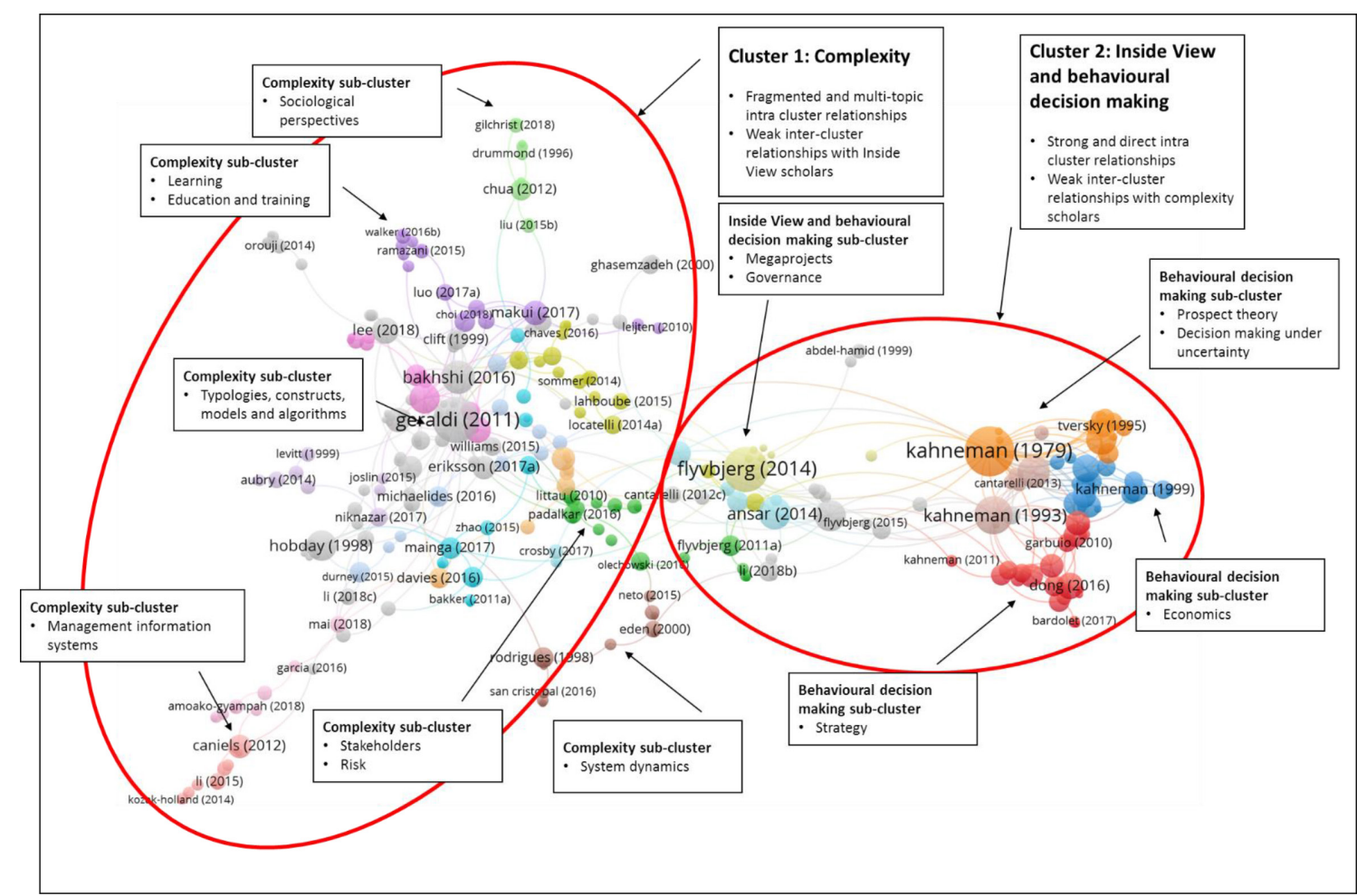

Figure 6 Citation analysis of papers concerning project complexity and the inside view. N=1 667 articles.

complexity, recognition of the impact of the inside view is relatively new territory.

\section{Discussion}

Flyvbjerg's focus on the inside view and Geraldi et al. (2011) conception of complexity as root sources of delivery risk belong to the 'proactive' risk paradigm (Lehtiranta, 2014, p. 647). This paradigm, which emerged during the explanatory era of project management research of the mid-80's, involves perceiving risk as a threat to project delivery performance that must be addressed (Padalkar and Gopinath, 2016a). The proactive paradigm of risk research is heavily influenced by a functional perspective which is normative, instrumentalist, hyper-rational, and emphasises deviation from expected norms such as cost, schedule and benefits targets (Lehtiranta, 2014; de Carvalho and Rabechini Junior, 2015). Under a proactive paradigm of risk, major project delivery fails because leaders do not adequately engage to remove, mitigate or provide contingency against them (Lehtiranta, 2014). Best practice risk management is seen as establishing performance norms, proactively identifying all possible sources of risk that threaten achievement of these norms, developing action plans and implementing them (Irimia-Diéguez et al., 2014). In pursuit of this agenda, a substantial body of delivery risk management research has developed detailed taxonomies of risk along with strategies to address them at all stages of the project life cycle - see for example (Al-Ahmad et al., 2009; Irimia-Diéguez et al., 2014; Kardes et al., 2013; Miller and Lessard, 2001; Shahhossein et al., 2017; Shehu and Akintoye, 2010; Whitney and Daniels, 2013).

In contrast to the taxonomical approach, scholars from the non-deterministic community identify their strand of delivery risk management research as pertaining to "root causes" of project delivery risk - and hence major project delivery failure. For instance, Flyvbjerg claims the root cause of project delivery risk emerges from the behavioural decision making and agency dynamics that bias ex-ante estimates against which project performance is ultimately assessed. Behavioural reductionists like Flyvbjerg search for the "roots of irrational decision behaviour .... [such as] bounded 
rationality and other cognitive biases ... optimism bias and planning fallacy ... prospect theory ... or illusion of control" (Stingl and Geraldi, 2017, p. 124). To these scholars, correcting these biases at the estimating stage is therefore a fundamental delivery risk mitigation (Flyvbjerg, 2013b).

Other scholars such as Maylor et al. (2013), Williams (2005) and Geraldi et al. (2011) identify complexity as a better representation of the root "realities" of projects compared to traditional mechanistic, causal approximations (Geraldi et al., 2011, p. 986; Maylor et al., 2013, p. 47) and promote directing attention to its perception, diagnosis and mitigation as central to managing delivery risk. As the chronological tally in Figure 3 shows, concentrated study of their relationship with each other has only emerged in the last decade of project management research.

More generally still, behavioural decision making has been identified as an important socio-political dimension to non-deterministic era research because decisions are foundational to management activity (Stingl and Geraldi, 2017). What is clear from this narrative review is how project complexity, project risk and project governance research has increasingly recognised behavioural and socio-political dimensions.

\section{Addressing the Research Questions}

The findings from the literature review comprise a heterogeneous mix of project management research that has been organised to describe the challenges, causes and cures to the root causes of project delivery risk that arise from complexity or the inside view. This material provided the basis for addressing the two research questions: (i) to determine the availability of research that addresses project complexity and the inside view as joint, rather than independent root causes of project delivery risk; and (ii) to determine what can be used to treat them as joint root causes of delivery risk in major projects.

\section{Considering the question, "What is the available research that treats com- plexity and the inside view as joint root}

\section{causes of project delivery risk for major projects?"}

The literature review identified the corpus of literature that addressed the challenges, causes and cures of the root causes of delivery risk arising from project complexity and/or the inside view. As the citation visualisations illustrate, authors tend not to refer to work from the other 'school of thought', though seven papers indicate that project delivery risk can be subject to joint effects from project complexity and the inside view. Consequently, the treatments in the literature of these two causes of project delivery risk can be concluded to be largely separate.

Where authors examined this joint effect and ways those perspectives can be combined, they tended to indicate how complexity impacts the inside view but not how the inside view exacerbates project complexity. Complexity can distort decision making when people use heuristics as shortcuts in the face of vast amounts of uncertain environmental data. For instance, Awojobi and Jenkins (2016, p. 26) indicate the complexity of engineering design for large dams results in optimistic estimates of key design parameters which can lead to underestimated capital costs and schedule duration. Similarly, Callegari et al. (2018) indicate the sheer scale of megadam projects results in a high degree of complexity. Trying to identify, describe and specify this complexity results in estimates of time, cost and benefits that are strongly influenced by the inside view, and therefore subject to untempered optimism bias and strategic misrepresentation.

Boateng et al. (2013) use a systems dynamic model to illustrate how social-technical-economicenvironmental-political factors can influence project delivery risk in complex-systemic fashion. Some of the circumstances when major projects exhibit all of these characteristics include: (i) during the dynamic stages of project delivery (Oehmen, 2015); (ii) making strategic decisions under conditions of stress such as severe resource or time constraint and/or crisis (Horvitz, 2013; Kowalski-Trakofler et al., 2003; Williams, 2005); and (iii) when managing a portfolio of interlinked programmes and major projects (Castro et al., 2017; Ko and Cheng, 2007; Petit, 2012). 
A key reason why literature on complexity and the inside view rarely overlap is that complexity tends to address the dynamic aspects of project delivery while most of the work on tempering the inside view applies during the relative clarity of the project front-end, particularly when establishing the final business case. For example, as the work of the complexity scholars show many of the complexity dynamics, and inherently the 'emergent' ones, exhibit their greatest influence on project delivery risk during project execution rather than project planning. The exclusion of the effect of the complex project execution stage on project outcomes is an important criticism of Reference Class Forecasting research (Ahiaga-Dagbui et al., 2017; Love, 2011).

\section{Considering the Question, "What Can Be Used to Treat Complexity and the Inside View as Joint Root Causes of Project Delivery Risk in Major Pro- jects?"}

The systematic literature review and snowball search identified seven papers (Awojobi and Jenkins, 2016; Bain, 2009a; Callegari et al., 2018; Catalão et al., 2019; Hetemi et al., 2017; Klakegg et al., 2016; Williams, 2005) that explicitly acknowledged the joint effect of project complexity and the inside view as root causes of project delivery risk. These papers recognised conventional reductionist project management methods handle delivery risks that arise from complexity and the inside view poorly and perform even worse when complexity and the inside view operate in combination. All seven papers proposed solutions for addressing project delivery risk. Synthesising this work, these papers collectively offered five strategies / approaches designed to jointly address the delivery risks arising from project complexity and the inside view, which were:

adopt a whole-of-project-lifecycle management approach rather than rigidly segmenting a project's front-end planning from its delivery;

be able to adapt to complexity not just technostructurally but also organisationally, socially and politically; emphasise project and organisational learning; increase transparency and accountability, and; incorporate outside view techniques to ameliorate optimism bias and strategic misrepresentation.

Each strategy appears laudable, yet operationalising them requires techniques that facilitate the necessary activities a project team need to undertake to employ the strategy and enable the achievement of their objective, ie, addressing the delivery risks arising from project complexity and the inside view. The literature review findings indicated that only the final strategy was supported with wellgrounded techniques, i.e. for applying the outside view to temper optimism bias and strategic misrepresentation. Here three techniques were reported: Reference Class Forecasting (Flyvbjerg, 2013b); Case Based Decision Theory (Lovallo et al., 2012, p. 497), and; Bayesian modelling (Matthews and Philip, 2012). These three techniques are considered in turn.

Reference Class Forecasting is applicable during project planning, specifically at the time the final business case is determined. This method calls for the identification and quantification of a representative sample of projects with the same characteristics to apply an outside view to producing probabilistic calculations of future outcomes and use this information to correct ex-ante final business case forecasts. Reference Class Forecasting is grounded in Kahneman and Tversky's theories on bias in ex-ante decision making and so cannot be employed at other stages of the project lifecycle. Were this approach extended to other stages of the project lifecycle it would need to overcome the practical challenge of identifying and quantifying performance at consistent points during delivery. Without the construct clarity and definitional rigour found at the 'final business case' investment decision stage, attempts to employ the outside view at 'in flight' reference points would lack robustness and therefore undermine the ability to inform forward looking predictions with certainty.

Case Based Decision Theory, and by enlargement Case Based Reasoning, Similarity Based Forecasting and cognate methods from artificial intelligence, may be useful techniques for extending the outside view into the project 
execution phase, in contrast to Reference Class Forecasting. The ability of Case Based Reasoning to solve, "a new problem by remembering a previous similar situation and reusing that information and knowledge of that situation" (Aamodt and Plaza, 1994, p. 40) and its more flexible retrieval architecture could potentially help. Similarity Based Forecasting helps decision makers, "make a fundamental psychological shift toward adopting an outside view", where, "the first step in the analysis of strategic problems is to begin with a list of similar endeavours", and "close analogies are a better basis for predictive performance" (Lovallo et al., 2012). This technique can also be used to treat complexity as, "Similarity judgments reflect 'dimension reduction' in mapping very complex objects onto a single scale" (Lovallo et al., 2012). Similarity Based Forecasting has its origins in Case Based Decision Theory which is an established subset of artificial intelligence. Machine learning methods from artificial intelligence could also prove useful to handle a wider variety of model and data types. Doing so allows data from multiple time sequences to be used and accommodates the parametric modelling techniques used in reference class forecasting along with non-parametric, nondeterministic, and non-linear methods (Buono et al., 2007; Dong and Sarkar, 2015; Dudek, 2015a; 2015b; Gilboa and Schmeidler, 1997; Murphy, 2012; Tsai, 2016; Wan et al., 2010). This capability suggests machine learning could address the challenges posed in the complex and dynamic project circumstances described earlier. Future empirical work should test the effectiveness of these prescriptions for ameliorating project risks that arise from the joint effect of complexity and the inside view.

Bayesian modelling uses prior knowledge of conditions relating to an event to describe the probability of the event occurring (Joyce, 2019). (Matthews and Philip, 2012) provide a comprehensive description of how a Bayesian approach can be applied to diagnose issues in project delivery and how this technique employs an outside view by utilising the historical performance of similar projects as its source of prior knowledge. The technique can also be viewed as addressing complexity, where Matthews and Philip illustrate its application with a range of problematic scenarios that are by their nature technical such as, "poor workmanship"; political, such as, "Political considerations make progress more difficult"; social such as, "Designer decisions that the client does not like", and; emergent, such as, "Increasing health \& safety needs". In doing so they show Bayesian modelling to be a technique that can enable decision makers, such as a project manager, to proactively investigate complexity and address the inside view as root causes of project delivery risk and pre-emptively treat them by initiating suitable mitigating actions.

\section{Directions for Future Research}

Broadly speaking, a schism was observed as having emerged between research into complexity and the inside view which prompts the need to investigate project delivery risk from these perspectives jointly. For instance, quantitative forecasts of project delivery risk is a regular and important activity during project execution that involves, "intuitive predictions and judgements of confidence" (Kahneman and Tversky, 1973, p. 237). Given these are fundamental project management activities they would benefit from a sounder basis on which decision makers could undertake and provide for, "prediction of uncertain quantities and the assessment of probability distributions" (Kahneman and Tversky, 1979, p. 314). Since these decisions are made within an organisational context, they will be subject to the effects of the inside view, and affected by the complexities emerging from the dynamics of project delivery. Yet by generally not recognising how complexity and the inside view jointly affect estimating activities such as these, the literature misses an opportunity to improve the performance of a significant proportion of project activities that are essential to delivering project outcomes that meet targets. Despite the emergence of research on the outside view for project planning, the many project execution activities that occur after final business case approval have yet to be exhaustively studied or benefit from this perspective.

The ability of Case Based Decision Theory as an outside view method has the potential to solve new problems by learning from history alongside 
its more flexible retrieval architecture. It is more flexible than Reference Class Forecasting and this suggests the potential to be applied during project execution to combat the joint effects of complexity and the inside view. It may therefore be possible to apply artificial intelligence methods to the outside view through Case Based Decision Theory and its derivatives.

Likewise, Bayesian modelling is shown to have substantial potential as a technique that can accommodate complexity in its various facets and also draw on the historical performance of similar projects to operationalise the outside view and jointly employ this understanding to inform decision making at the planning stage as well as during project execution.

Future empirical work should test the effectiveness of these prescriptions for ameliorating project delivery risks that arise from the joint effect of complexity and the inside view. This may provide fertile opportunity for employing machine learning to assist in addressing complex and dynamic challenges found in major project delivery.

\section{Conclusion}

This paper used a systematic literature review, snowball literature search and citation analyses to answer two research questions regarding root causes of project delivery risk. In summary, this research identified mechanisms and the potential benefit of treating project complexity and the inside view as joint root causes of delivery risk.

Addressing the first research question, "What is the available research that treats complexity and the inside view as joint root causes of project delivery risk for Major Projects?" showed that there is little theoretical or empirical evidence of approaches that deal with both complexity and the inside view as joint root causes of delivery risk. An implication for scholars from this finding is that the literature reports a tendency to regard project complexity and the inside view as separate issues that have separate treatments. This suggests that there may be substantial benefits in improving project delivery risk management if methods were found to integrate these two root causes of risk as a new strand of risk research.

Considering the second research question, "What can be used to treat complexity and the inside view as joint root causes of project delivery risk in major projects?" revealed several possible methods for attending to the joint risks of project complexity and the inside view. An implication from this finding that is relevant to policymakers is that to reduce delivery risks that arise from the joint effect of project complexity and the inside view, extant research provides five project governance and project management strategies / approaches: (i) adopt a whole-of-project-lifecycle management approach rather than rigidly segmenting a project's front-end planning from its delivery; (ii) be able to adapt to complexity not just technically but also organo-socio-politically; (iii) emphasise project and organisational learning; (iv) increase transparency and accountability; and (v) apply the outside view to temper optimism bias and strategic representation. Of note for practitioners, to operationalise the strategy of applying the outside view, the research identified Case Based Decision Theory / Case Based Reasoning and Bayesian model averaging were identified as potential methods for adapting the outside view to the complexities of project delivery.

The two contributions of this paper are that it has: (i) identified an important gap in the research on root causes of project delivery risk by showing how project complexity and the inside view can be joint root causes of risk for some common project activities; and (ii) identified Case Based Decision Theory / Case Based Reasoning, and Bayesian modelling as techniques with the potential for attenuating delivery risks that arise from the joint effects of the inside view and project complexity. Further empirical research using real project data is required to validate these methods.

\section{Limitations}

This paper has drawn upon research from the project management literature concerning project complexity and the inside view as root causes of project delivery risk. While there has been increasing progress in recognising the social, organisational and political aspects of project 
complexity, the field has only just begun to study these aspects. In addition, research into the inside view for projects is relatively recent, and, due to methodological challenges, some scholars have argued it lacks full empirical evidence to support its claims. Moreover, there is a relatively small body of literature that describes the joint consideration of complexity and the inside view. Indeed, this paper only identified seven published articles on the joint effect of complexity and the inside view, the oldest of which is only 13 years old. Empirical testing of the effectiveness of the cures to these joint effects is lacking and thus presents a new research opportunity.

\section{References}

Aamodt, A. and Plaza, E. (1994), "Case-Based Reasoning: foundational issues, methodological variations, and system approaches", AI Communications, Vol. 7 No. 1, pp. 39-59. 10.3233/AIC-1994-7104

Ahiaga-Dagbui, D.D., Love, P.E.D., Smith, S.D. and Ackermann, F. (2017), "Toward a systemic view to cost Overrun causation in infrastructure projects: a review and implications for research", Project Management Journal, Vol. 48 No. 2, pp. 88-98. 10.1177/875697281704800207

Al-Ahmad, W., Al-Fagih, K., Khanfar, K., Alsamara, K., Abuleil, S. and Abu-Salem, H. (2009), "A taxonomy of an it project failure: root causes", International Management Review, Vol. 5, p. 13.

Ansar, A., Flyvbjerg, B., Budzier, A. and Lunn, D. (2014), "Should we build more large dams? the actual costs of hydropower megaproject development", Energy Policy, Vol. 69 No. 2, pp. 43-56. 10.1016/j.enpol.2013.10.069

Antoniadis, D.N., Edum-Fotwe, F.T. and Thorpe, A. (2011), "Socio-organo complexity and project performance", International Journal of Project Management, Vol. 29 No. 7, pp. 808-816. 10.1016/j. ijproman.2011.02.006

Artto, K., Martinsuo, M., Gemünden, H.G. and Murtoaro, J. (2009), "Foundations of program management: a bibliometric view", International Journal of Project Management, Vol. 27 No. 1, pp. 1-18. 10.1016/j.ijproman.2007.10.007

Australian Government,. (2020), "Current Major Projects [WWW Document]", available at: /grants-andprograms/major-project-status/current-major-projects [accessed Nov 25, 2020].
Avots, I. (1969), "Why does project management fail?" California Management Review, Vol. 12 No. 1, pp. 77-82. 10.2307/41164208

Awojobi, O. and Jenkins, G.P. (2016), "Managing the cost overrun risks of hydroelectric dams: an application of reference class forecasting techniques", Renewable and Sustainable Energy Reviews, Vol. 63 No. 4, pp. 19-32. 10.1016/j.rser.2016.05.006

Bain, R. (2009a), "Error and optimism bias in toll road traffic forecasts", Transportation, Vol. 36 No. 5, pp. 469-482. 10.1007/s11116-009-9199-7

Bain, R. (2009b), "Error and optimism bias in toll road traffic forecasts", Transportation, Vol. 36 No. 5, pp. 469-482. 10.1007/s11116-009-9199-7

Bakhshi, J., Ireland, V. and Gorod, A. (2016), "Clarifying the project complexity construct: past, present and future", International Journal of Project Management, Vol. 34 No. 7, pp. 1199-1213. 10.1016/j. ijproman.2016.06.002

Barnes, N.M.L. and Wearne, S.H. (1993), "The future for major project management", International Journal of Project Management, Vol. 11 No. 3, pp. 135-142. 10.1016/0263-7863(93)90046-P

Bartlett, J. (2004), Project Risk Analysis and Management Guide. UK: APM Publishing Limited.

Batselier, J. and Vanhoucke, M. (2016), "Practical application and empirical evaluation of reference class forecasting for project management", Project Management Journal, Vol. 47 No. 5, pp. 36-51. 10.1177/875697281604700504

Bayram, S. and Al-Jibouri, S. (2016a), "Efficacy of Estimation Methods in Forecasting Building Projects' Costs", Journal of Construction Engineering and Management, Vol. 142 No. 11, p. 05016012. 10.1061/(ASCE)CO.1943-7862.0001183

Bayram, S. and Al-Jibouri, S. (2016b), “Application of reference class forecasting in Turkish public construction projects: contractor perspective", Journal of Management in Engineering, Vol. 32 No. 3, p. 05016002. 10.1061/(ASCE)ME.1943-5479.0000421

Biesenthal, C. and Wilden, R. (2014), "Multi-Level project governance: trends and opportunities", International Journal of Project Management, Vol. 32 No. 8, pp. 1291-1308. 10.1016/j.ijproman.2014.06.005

Boateng, P., Chen, Z., Ogunlana, S. and Ikediashi, D. (2013), "A system dynamics approach to risks description in megaprojects development", Organization, Technology \& Management in Construction in international journal, Vol. 4 No. 3, pp. 593-603.

Bordley, R.F. (2014), "Reference class forecasting: resolving its challenge to statistical modeling", The

Engineering Project Organization Journal

(C) 2021 Engineering Project Organization Society www.epossociety.org 
American Statistician, Vol. 68 No. 4, pp. 221-229. 10.1080/00031305.2014.937544

Bosch-Rekveldt, M., Jongkind, Y., Mooi, H., Bakker, H. and Verbraeck, A. (2011), "Grasping project complexity in large engineering projects: the toe (technical, organizational and environmental) framework", International Journal of Project Management, Vol. 29 No. 6, pp. 728-739. 10.1016/j. ijproman.2010.07.008

Boyer, G. and McKinnon, M. (2015), “Development and displacement risks", Forced Migration Review, pp. 21-22.

Briner, R.B. and Denyer, D. (2012), "Systematic review and evidence synthesis as a practice and scholarship tool". In: Rousseau D. M, ed, The Oxford Handbook of Evidence-Based Management. pp. 112-129.

Buono, P., Plaisant, C., Simeone, A., Aris, A., Shmueli, G. and Jank, W. (2007), "Similarity-Based forecasting with simultaneous Previews: a river plot interface for time series forecasting. IEEE”, pp. 191-196.

Callegari, C., Szklo, A. and Schaeffer, R. (2018), “Cost overruns and delays in energy megaprojects: how big is big enough?" Energy Policy, Vol. 114, pp. 211-220. 10.1016/j.enpol.2017.11.059

Cantarelli, C.C., Flybjerg, B., Molin, E.J. and Van Wee, B. (2010a), "Cost overruns in large-scale transportation infrastructure projects: explanations and their theoretical embeddedness", European Journal of Transport and Infrastructure Research, Vol. 1, pp. 5-18.

Cantarelli, C.C., Flyvbjerg, B., van Wee, B. and Molin, E.J.E. (2010b), "Lock-In and its influence on the project performance of large-scale transportation infrastructure projects: investigating the way in which lock-in can emerge and affect cost overruns", Environment and Planning B: Planning and Design, Vol. 37 No. 5, pp. 792-807. 10.1068/b36017

Castro, J.F.Tde., Costa, H.G., Méxas, M.P. and Caiado, R.G.G. (2017), “The Influence of Schedule Changes in a Portfolio of Projects and Operations with Shared Resources - A Case Study", Revista de Gestão e Projetos, Vol. 08, pp. 100-117.

Catalão, F.P., Cruz, C.O. and Sarmento, J.M. (2019), "The determinants of cost deviations and overruns in transport projects, an endogenous models approach", Transport Policy, Vol. 74 No. 1, pp. 224-238. 10.1016/j.tranpol.2018.12.008

Chapman, R.J. (2016), “A framework for examining the dimensions and characteristics of complexity inherent within rail megaprojects", International
Journal of Project Management, Vol. 34 No. 6, pp. 937-956. 10.1016/j.ijproman.2016.05.001

Cooke-Davies, T., Cicmil, S., Crawford, L. and Richardson, K. (2007), "We're not in Kansas anymore, TOTO: mapping the strange landscape of complexity theory, and its relationship to project management", Project Management Journal, Vol. 38 No. 2, pp. 50-61. 10.1177/875697280703800206

Cramer, K. (2020), A Political History of Big Science: The Other Europe, Palgrave Studies in the History of Science and Technology. London, UK: Palgrave Macmillan.

Daniel, E. and Daniel, P.A. (2019), "Megaprojects as complex adaptive systems: the Hinkley point $\mathrm{C}$ case", International Journal of Project Management, Vol. 37 No. 8, pp. 1017-1033. 10.1016/j. ijproman.2019.05.001

Carvalho, M.Mde. and Rabechini Junior, R. (2015), "Impact of risk management on project performance: the importance of soft skills", International Journal of Production Research, Vol. 53 No. 2, pp. 321-340. 10.1080/00207543.2014.919423

De Jong, M., Annema, J.A. and Van Wee, G.P. (2013), "How to build major transport infrastructure projects within budget, in time and with the expected output; a literature review", Transport Reviews, Vol. 33 No. 2, pp. 195-218. 10.1080/01441647.2013.778912

De Rezende, L.B., Blackwell, P. and Pessanha Gonçalves, M.D. (2018), "Research focuses, trends, and major findings on project complexity: a bibliometric network analysis of 50 years of project complexity research", Project Management Journal, Vol. 49 No. 1, pp. 42-56. 10.1177/875697281804900104

Denyer, D. and Tranfield, D. (2009), "Producing a systematic review". In: Buchanan D, Bryman A, eds, The SAGE Handbook of Organizational Research Methods. London: Sage Publications. pp. 671-689.

Dong, A. and Sarkar, S. (2015), "Forecasting technological progress potential based on the complexity of product knowledge", Technological Forecasting and Social Change, Vol. 90, pp. 599-610. 10.1016/j. techfore.2014.02.009

Dudek, G. (2015a), "Pattern similarity-based methods for short-term load forecasting - Part 2: models", Applied Soft Computing, Vol. 36 No. 1, pp. 422441. 10.1016/j.asoc.2015.07.035

Dudek, G. (2015b), "Pattern similarity-based methods for short-term load forecasting - Part 1: principles", Applied Soft Computing, Vol. 37 No. 4, pp. 277287. 10.1016/j.asoc.2015.08.040

Durney, C.P. and Donnelly, R.G. (2015), "Managing the effects of rapid technological change on complex information technology projects", Journal of

Engineering Project Organization Journal

(C) 2021 Engineering Project Organization Society www.epossociety.org 
the Knowledge Economy, Vol. 6 No. 4, pp. 641-664. 10.1007/s13132-012-0099-2

Eliasson, J. and Fosgerau, M. (2013), “Cost overruns and demand shortfalls - deception or selection?" Transportation Research Part B: Methodological, Vol. 57 No. 5, pp. 105-113. 10.1016/j. trb.2013.09.005

Emmons, D.L., Mazzuchi, T.A., Sarkani, S. and Larsen, C.E. (2018), Mitigating Cognitive Biases in Risk Identification: Practioner Checklist for the Aerospace Sector. vol. 25. Fort Belvoir: Defense AR Journal. pp. 52-93.

Flis, I. and van Eck, N.J. (2017), "Framing psychology as a discipline (1950-1999): a large-scale term co-occurrence analysis of scientific literature in psychology", History of Psychology, Vol. 21 No. 4, pp. 334-362. 10.1037/hop0000067

Flyvbjerg, B. (2006), "From Nobel Prize to project management: getting risks right", Project Management Journal, Vol. 37 No. 3, pp. 5-15. 10.1177/875697280603700302

Flyvbjerg, B. (2007), "Policy and planning for LargeInfrastructure projects: problems, causes, cures", Environment and Planning B: Planning and Design, Vol. 34 No. 4, pp. 578-597. 10.1068/b32111

Flyvbjerg, B. (2009), "Survival of the unfittest: why the worst infrastructure gets built--and what we can do about it", Oxford Review of Economic Policy, Vol. 25 No. 3, pp. 344-367. 10.1093/oxrep/grp024

Flyvbjerg, B. (2011), Over Budget, Over Time, Over and Over Again [WWW Document]. Oxford, UK: The Oxford Handbook of Project Management.

Flyvbjerg, B. (2013a), “Quality control and due diligence in project management: getting decisions right by taking the outside view", International Journal of Project Management, Vol. 31 No. 5, pp. 760-774. 10.1016/j.ijproman.2012.10.007

Flyvbjerg, B. (2013b), "Quality control and due diligence in project management: getting decisions right by taking the outside view", International Journal of Project Management, Vol. 31 No. 5, pp. 760-774. 10.1016/j.ijproman.2012.10.007

Flyvbjerg, B. (2014), "What you should know about Megaprojects and why: an overview", Project Management Journal, Vol. 45 No. 2, pp. 6-19. 10.1002/ pmj.21409

Flyvbjerg, B. ed (2017). The Oxford Handbook of Megaproject Management. Oxford University Press: Oxford.

Flyvbjerg, B., Ansar, A., Budzier, A., Buhl, S., Cantarelli, C., Garbuio, M., Glenting, C., Holm, M.S., Lovallo, D., Lunn, D., Molin, E., Rønnest, A.,
Stewart, A. and van Wee, B. (2018), "Five things you should know about cost overrun", Transportation Research Part A: Policy and Practice, Vol. 118, pp. 174-190.

Flyvbjerg, B., Ansar, A., Budzier, A., Buhl, S., Cantarelli, C., Garbuio, M., Glenting, C., Skamris Holm, M.K., Lovallo, D., Molin, E., Rønnest, A., Stewart, A. and van Wee, B. (2019), "On de-bunking "Fake News" in the post-truth era: How to reduce statistical error in research", Transportation Research Part A: Policy and Practice, Vol. 126, pp. 409-411.

Flyvbjerg, B. and Budzier, A. (2011), "Why your it project may be Riskier than you think", SSRN Electronic Journal. 10.2139/ssrn.2229735

Flyvbjerg, B., Garbuio, M. and Lovallo, D. (2009), "Delusion and deception in large infrastructure projects: two models for explaining and preventing executive disaster", California Management Review, Vol. 51 No. 2, pp. 170-194. 10.2307/41166485

Flyvbjerg, B., Holm, M.S. and Buhl, S. (2002), "Underestimating Costs in Public Works Projects: Error or Lie?" Journal of the American Planning Association, Vol. 68 No. 3, pp. 279-295. $10.1080 / 01944360208976273$

Flyvbjerg, B., Hon, C.-keung. and Fok, W.H. (2016), "Reference class forecasting for Hong Kong's major roadworks projects", Proceedings of the Institution of Civil Engineers - Civil Engineering, Vol. 169 No. 6, pp. 17-24. 10.1680/jcien.15.00075

Flyvbjerg, B. and Stewart, A. (2012), “Olympic proportions: cost and cost Overrun at the Olympics 1960-2012”, SSRN Electronic Journal, Vol. 23 No. 2. $10.2139 /$ ssrn. 2238053

Geraldi, J., Maylor, H. and Williams, T. (2011), "Now, let's make it really complex (complicated): A systematic review of the complexities of projects", International Journal of Operations \& Production Management, Vol. 31, pp. 966-990.

Gilboa, I. and Schmeidler, D. (1997), "Act similarity in case-based decision theory", Economic Theory, Vol. 9 No. 1, pp. 47-61. 10.1007/BF01213442

Gordon, S. (2017), "A systematic look at major programmes. NAO blog", available at: https:/www. nao.org.uk/naoblog/a-systematic-look-at-major-programmes/ [accessed Nov 20, 2020].

Gothelf, J. and Seiden, J. (2017), You Need to Manage Digital Projects for Outcomes, Not Outputs. USA: Harvard Business Review Digital Articles. pp. 2-6.

Grant, D. (2016), "Business analysis techniques in business reengineering", Business Process Management Journal, Vol. 22 No. 1, pp. 75-88. 10.1108/ BPMJ-03-2015-0026

Engineering Project Organization Journal

(C) 2021 Engineering Project Organization Society www.epossociety.org 
Haji-Kazemi, S. and Andersen, B. (2014), “Efficiency of project health checks (PHCs) as an early warning system in practice: A case study in Norway's telecommunication industry", International Journal of Managing Projects in Business, Vol. 7, pp. 678-700.

Haji-kazemi, S., Andersen, B., Eleftheriadis, R. and Capellan, A. (2015), "The early warning procedure in an international context", Procedia - Social and Behavioral Sciences, Vol. 194 No. 2, pp. 85-95. 10.1016/j.sbspro.2015.06.122

Hetemi, E., Mere, J.O., Nuur, C. and Engwall, M. (2017), "Exploring mechanisms underlying lock-in in large infrastructure projects: a management perspective", Procedia Computer Science, Vol. 121 No. 5, pp. 681-691. 10.1016/j.procs.2017.11.089

Holland, A. and Fathi, M. (2007), "Quantitative and qualitative risk in IT portfolio management, in: Systems, Man and Cybernetics", ISIC. IEEE International Conference On. IEEE. 3840-3847.

Holweg, M. and Maylor, H. (2018), "Lean leadership in major projects: from "predict and provide" to "predict and prevent"", International Journal of Operations \& Production Management, Vol. 38 No. 6, pp. 1368-1386. 10.1108/IJOPM-02-2017-0100

Horvitz, E.J. (2013), "Reasoning about beliefs and actions under computational resource constraints", ArXiv, arXiv:1304.2759. preprint.

Infrastructure and Projects Authority,. (2020), Annual Report on Major Projects. pp. 2019-2020.

Institute for Government. (2020), "Major projects [WWW Document]. The Institute for Government", available at: https:/www.instituteforgovernment. org.uk/publication/whitehall-monitor-2020/majorprojects [accessed Nov 20, 2020].

Irimia-Diéguez, A.I., Sanchez-Cazorla, A. and Alfalla-Luque, R. (2014), "Risk management in Megaprojects", Procedia - Social and Behavioral Sciences, Vol. 119, pp. 407-416. 10.1016/j.sbspro.2014.03.046

Jacoby, K. (2017), "Federal Highway Administration Major Project Guidance [WWW Document]", available at: https://www.fhwa.dot.gov/majorprojects/ resources/faqs.cfm [accessed Nov 25, 2020].

Jan, N. and Waltman, L. (2018), VOSviewer. The Netherlands: Centre for Science and Technology Studies, Leiden University.

Johnson, G. (1992), "Managing strategic changestrategy, culture and action", Long Range Planning, Vol. 25 No. 1, pp. 28-36. 10.1016/00246301(92)90307-N

Jolivet, F. and Navarre, C. (1996), "Large-Scale projects, self-organizing and meta-rules: towards new forms of management", International Journal of
Project Management, Vol. 14 No. 5, pp. 265-271. 10.1016/0263-7863(96)84509-1

Joyce, J. (2019), “Bayes' Theorem [WWW Document]. The Stanford Encyclopedia of Philosophy", available at: https://plato.stanford.edu/archives/spr2019/ entries/bayes-theorem/ [accessed Dec 1, 2020].

Kahneman, D. and Lovallo, D. (1993), "Timid choices and BOLD forecasts: a cognitive perspective on risk taking", Management Science, Vol. 39 No. 1, pp. 17-31. 10.1287/mnsc.39.1.17

Kahneman, D. and Tversky, A. (1973), "On the psychology of prediction", Psychological Review, Vol. 80 No. 4, pp. 237-251. 10.1037/h0034747

Kahneman, D. and Tversky, A. (1979), "Intuitive prediction: biases and corrective procedures", TIMS Studies in the Management Sciences, Vol. 12, pp. 313-327.

Kaiser, M.J. and Snyder, B. (2012), "Offshore wind capital cost estimation in the U", S. Outer Continental Shelf-A reference class approach. Marine Policy, Vol. 36, pp. 1112-1122.

Kardes, I., Ozturk, A., Cavusgil, S.T. and Cavusgil, E. (2013), "Managing global megaprojects: complexity and risk management", International Business Review, Vol. 22 No. 6, pp. 905-917. 10.1016/j. ibusrev.2013.01.003

Klakegg, O.J., Williams, T. and Shiferaw, A.T. (2016), "Taming the 'trolls': Major public projects in the making", International Journal of Project Management, Vol. 34 No. 2, pp. 282-296. 10.1016/j. ijproman.2015.03.008

Koch, C. (2012), "Contested overruns and performance of offshore wind power plants", Construction Management and Economics, Vol. 30 No. 8, pp. 609-622. 10.1080/01446193.2012.687830

Ko, C.-H. and Cheng, M.-Y. (2007), "Dynamic prediction of project success using artificial intelligence", Journal of Construction Engineering and Management, Vol. 133 No. 4, pp. 316-324. 10.1061/ (ASCE)0733-9364(2007)133:4(316)

Kowalski-Trakofler, K.M., Vaught, C. and Scharf, T. (2003), "Judgment and decision making under stress: an overview for emergency managers", International Journal of Emergency Management, Vol. 1 No. 3, pp. 278-289. 10.1504/IJEM.2003.003297

Krauskopf, E. (2018), "A bibiliometric analysis of the Journal of infection and public health: 2008-2016", Journal of Infection and Public Health, Vol. 11 No. 2, pp. 224-229. 10.1016/j.jiph.2017.12.011

Lehtiranta, L. (2014), "Risk perceptions and approaches in multi-organizations: a research review 2000-2012”, International Journal of Project

Engineering Project Organization Journal

(C) 2021 Engineering Project Organization Society www.epossociety.org 
Management, Vol. 32 No. 4, pp. 640-653. 10.1016/j. ijproman.2013.09.002

Leleur, S., Salling, K.B., Pilkauskiene, I. and Nicolaisen, M.S. (2015), "Combining reference class forecasting with Overconfidence theory for better risk assessment of transport infrastructure investments", European Journal of Transport and Infrastructure Research, Vol. 15, pp. 362-375.

LeRoy, S.F. and Singell,, L.D. (1987), "Knight on risk and uncertainty", Journal of Political Economy, Vol. 95 No. 2, pp. 394-406. 10.1086/261461

Li, J., Slyngstad, O.P.N., Torchiano, M., Morisio, M. and Bunse, C. (2008), "A State-of-the-Practice survey of risk management in development with off-the-shelf software components", IEEE Transactions on Software Engineering, Vol. 34, pp. 271-286.

Liu, L., Borman, M. and Gao, J. (2014), "Delivering complex engineering projects: reexamining organizational control theory", International Journal of Project Management, Vol. 32 No. 5, pp. 791-802. 10.1016/j.ijproman.2013.10.006

Lovallo, D., Clarke, C. and Camerer, C. (2012), "Robust analogizing and the outside view: two empirical tests of case-based decision making”, Strategic Management Journal, Vol. 33 No. 5, pp. 496-512. 10.1002/smj.962

Lovallo, D. and Kahneman, D. (2003), "Delusions of success. How optimism undermines executives' decisions", Harvard Business Review, Vol. 81 No. 7, pp. 56-63.

Love, P.E.D. (2011), "Plugging the Gaps' Between Optimum Bias and Strategic Misrepresentation and Infrastructure Cost Overruns", Procedia Engineering, Vol. 14 No. 1, pp. 1197-1204. 10.1016/j. proeng.2011.07.150

Love, P.E.D. and Ahiaga-Dagbui, D.D. (2018), "Debunking fake news in a post-truth era: the plausible untruths of cost underestimation in transport infrastructure projects", Transportation Research Part A: Policy and Practice, Vol. 113 No. 2, pp. 357-368. 10.1016/j.tra.2018.04.019

Love, P.E.D., Ahiaga-Dagbui, D.D. and Irani, Z. (2016), "Cost overruns in transportation infrastructure projects: sowing the seeds for a probabilistic theory of causation", Transportation Research Part A: Policy and Practice, Vol. 92 No. 1, pp. 184-194. 10.1016/j.tra.2016.08.007

Love, P.E.D., Holt, G.D., Shen, L.Y., Li, H. and Irani, Z. (2002), "Using systems dynamics to better understand change and rework in construction project management systems", International Journal of
Project Management, Vol. 20 No. 6, pp. 425-436. 10.1016/S0263-7863(01)00039-4

Mackie, P. and Preston, J. (1998), "Twenty-One sources of error and bias in transport project appraisal", Transport Policy, Vol. 5 No. 1, pp. 1-7. 10.1016/ S0967-070X(98)00004-3

Major Projects Association. (n.d), "Who We Are. Who We Are", available at: https://majorprojects.org/ about/ [accessed Nov 20, 2020].

Makovšek, D. (2014), "Systematic construction risk, cost estimation mechanism and unit price movements", Transport Policy, Vol. 35 No. 22, pp. 135-145. 10.1016/j.tranpol.2014.04.012

Markus, M.L. and Benjamin, R I. (1997), "The magic bullet theory in IT-Enabled transformation", Sloan management review, Vol. 38, pp. 55-68.

Matthews, P.C. and Philip, A.D.M. (2012), "Bayesian project diagnosis for the construction design process", Artificial Intelligence for Engineering Design, Analysis and Manufacturing, Vol. 26 No. 4, pp. 375-391. 10.1017/S089006041200025X

Maylor, H.R., Turner, N.W. and Murray-Webster, R. (2013), "How hard can it be?: actively managing complexity in technology projects", ResearchTechnology Management, Vol. 56 No. 4, pp. 45-51. 10.5437/08956308X5602125

Merrow, E.W. (1988), Understanding the Outcomes of Megaprojects - A Quantitative Analysis of Very Large Civilian Projects (No. 0833008439). Santa Monica, CA: RAND Corporation.

Maylor, H., Turner, N. and Murray-Webster, R. (2015), “"'It worked for manufacturing. . !". Operations strategy in project-based operations", International Journal of Project Management, Vol. 33, pp. 103-115.

Miller, R. and Lessard, D. (2001), "Understanding and managing risks in large engineering projects", International Journal of Project Management, Vol. 19 No. 8, pp. 437-443. 10.1016/S02637863(01)00045-X

Miranda Sarmento, J. and Renneboog, L. (2017), "Cost Overruns in public sector investment projects", Public Works Management \& Policy, Vol. 22 No. 2, pp. 140-164. $10.1177 / 1087724 X 16668357$

Montealegre, R. and Keil, M. (2000), “De-Escalating information technology projects: lessons from the Denver International Airport", MIS Quarterly, Vol. 24 No. 3, p. 417. 10.2307/3250968

Murphy, K.P. (2012), Machine learning: a probabilistic perspective, Adaptive computation and machine learning series. Cambridge, MA: MIT Press. 
Naess, P., Andersen, J.A., Nicolaisen, M.S. and Strand, A. (2015), "Forecasting inaccuracies: a result of unexpected events, optimism bias, technical problems, or strategic misrepresentation?" Journal of Transport and Land Use, Vol. 8. 10.5198/jtlu.2015.719

National Audit Office. (2020), Lessons learned from Major Programmes.

NYC Office of the Mayor, USA Office of Management and Budget, Department of Education, Administration for Children's Services. (2014), Ready to Launch: New York City's Implementation Plan for Free, High-Quality, Full-Day. New York: Universal Pre-Kindergarten.

Oehmen, J. (2015), Complexity Management for Projects, Programmes, and Portfolios: An Engineering Systems Perspective. PA, USA: Project Management Institute.

Olsson, N.O.E., Krane, H.P., Rolstadås, A. and Veiseth, M. (2010), "Influence of reference points in ex post evaluations of rail infrastructure projects", Transport Policy, Vol. 17 No. 4, pp. 251-258. 10.1016/j. tranpol.2010.01.008

Osland, O. and Strand, A. (2008), Evaluating large transport infrastructure projects - a criticalconstructive review of the theory of strategic misrepresentation. NJ, USA: IEEE. pp. 1-5.

Padalkar, M. and Gopinath, S. (2016a), "Six decades of project management research: thematic trends and future opportunities", International Journal of Project Management, Vol. 34 No. 7, pp. 1305-1321. 10.1016/j.ijproman.2016.06.006

Padalkar, M. and Gopinath, S. (2016b), "Are complexity and uncertainty distinct concepts in project management? A taxonomical examination from literature", International Journal of Project Management, Vol. 34 No. 4, pp. 688-700. 10.1016/j. ijproman.2016.02.009

Palmblad, M. and van Eck, N.J. (2018), "Bibliometric analyses reveal patterns of collaboration between ASMS members", Journal of The American Society for Mass Spectrometry, Vol. 29 No. 3, pp. 447-454. 10.1007/s13361-017-1846-1

Patanakul, P. (2014), "Managing large-scale IS/IT projects in the public sector: problems and causes leading to poor performance", The Journal of High Technology Management Research, Vol. 25 No. 1, pp. 21-35. 10.1016/j.hitech.2013.12.004

Patanakul, P., Kwak, Y.H., Zwikael, O. and Liu, M. (2016), "What impacts the performance of largescale government projects?" International Journal of Project Management, Vol. 34 No. 3, pp. 452-466. 10.1016/j.ijproman.2015.12.001
Pellegrinelli, S. (2011), "What's in a name: Project or programme?" International Journal of Project Management, Vol. 29 No. 2, pp. 232-240. 10.1016/j. ijproman.2010.02.009

Pellegrinelli, S., Partington, D., Hemingway, C., Mohdzain, Z. and Shah, M. (2007), "The importance of context in programme management: an empirical review of programme practices", International Journal of Project Management, Vol. 25 No. 1, pp. 41-55. 10.1016/j.ijproman.2006.06.002

Petit, Y. (2012), "Project portfolios in dynamic environments: organizing for uncertainty", International Journal of Project Management, Vol. 30 No. 5, pp. 539-553. 10.1016/j.ijproman.2011.11.007

Pich, M.T., Loch, C.H. and Meyer, A.D. (2002), “On uncertainty, ambiguity, and complexity in project management", Management Science, Vol. 48 No. 8, pp. 1008-1023. 10.1287/mnsc.48.8.1008.163

Prater, J., Kirytopoulos, K. and Ma, T. (2017), “Optimism bias within the project management context: a systematic quantitative literature review", International Journal of Managing Projects in Business, Vol. 10, pp. 370-385.

Priemus, H., van Wee, B. eds (2013). International Handbook on Mega-Projects. Edward Elgar Publishing Limited: Massachusetts.

Qazi, A., Quigley, J., Dickson, A. and Kirytopoulos, K. (2016), "Project complexity and risk management (ProCRiM): towards modelling project complexity driven risk paths in construction projects", International Journal of Project Management, Vol. 34 No. 7, pp. 1183-1198. 10.1016/j.ijproman.2016.05.008

Ramkumar, M., Schoenherr, T. and Jenamani, M. (2016), "Risk assessment of outsourcing eprocurement services: integrating SWOT analysis with a modified ANP-based fuzzy inference system", Production Planning \& Control, Vol. 13 No. 9, pp. 1-20. 10.1080/09537287.2016.1190877

Rouse, W.B. (2005), "A theory of enterprise transformation", Systems Engineering, Vol. 8 No. 4, pp. 279-295. 10.1002/sys.20035

Rousseau, D.M., Manning, J. and Denyer, D. (2008), "11 Evidence in Management and Organizational Science: Assembling the Field's Full Weight of Scientific Knowledge Through Syntheses", Academy of Management Annals, Vol. 2 No. 1, pp. 475-515. $10.5465 / 19416520802211651$

Salling, K.B. and Banister, D. (2009), "Assessment of large transport infrastructure projects: the CBA-DK model", Transportation Research Part A: Policy and Practice, Vol. 43 No. 9-10, pp. 800-813. 10.1016/j.tra.2009.08.001

Engineering Project Organization Journal

(C) 2021 Engineering Project Organization Society www.epossociety.org 
Salling, K.B. and Leleur, S. (2015a), “Accounting for the inaccuracies in demand forecasts and construction cost estimations in transport project evaluation", Transport Policy, Vol. 38 No. 5, pp. 8-18. 10.1016/j.tranpol.2014.11.006

Salling, K.B. and Leleur, S. (2015b), "Transport project evaluation: feasibility risk assessment and scenario forecasting", Transport, Vol. 32 No. 2, pp. 180-191. 10.3846/16484142.2015.1063003

Sample, J.A. (2015), Mitigating the Planning Fallacy in Project Forecasting An OD Perspective. vol. 33. Chesterland: Organization Development Journal. pp. 51-66.

Sauser, B.J., Reilly, R.R. and Shenhar, A.J. (2009), "Why projects fail? How contingency theory can provide new insights - A comparative analysis of NASA's Mars Climate Orbiter loss", International Journal of Project Management, Vol. 27 No. 7, pp. 665-679. 10.1016/j.ijproman.2009.01.004

Shahhossein, V., Afshar, M.R. and Amiri, O. (2017), "The root causes of construction project failure", Scientia Iranica, Vol. 25, pp. 93-108. 10.24200/ sci.2017.4178

Shehu, Z. and Akintoye, A. (2010), "Major challenges to the successful implementation and practice of programme management in the construction environment: a critical analysis", International Journal of Project Management, Vol. 28 No. 1, pp. 26-39. 10.1016/j.ijproman.2009.02.004

Sovacool, B.K., Gilbert, A. and Nugent, D. (2014a), "Risk, innovation, electricity infrastructure and construction cost overruns: testing six hypotheses", Energy, Vol. 74 No. 4, pp. 906-917. 10.1016/j. energy.2014.07.070

Sovacool, B.K., Gilbert, A. and Nugent, D. (2014b), "An international comparative assessment of construction cost overruns for electricity infrastructure", Energy Research \& Social Science, Vol. 3 No. 4, pp. 152-160. 10.1016/j.erss.2014.07.016

Stingl, V. and Geraldi, J. (2017), "Errors, lies and misunderstandings: systematic review on behavioural decision making in projects", International Journal of Project Management, Vol. 35 No. 2, pp. 121-135. 10.1016/j.ijproman.2016.10.009

Taherdoost, H., Keshavarzsaleh, A., Wang, C. and Liu, S. (2016), “A retrospective critic Re-Debate on Stakeholders' resistance checklist in software project management within multi-cultural, multi-ethnical and cosmopolitan society context: The Malaysian experience", Cogent Business \& Management, Vol. 3 No. 11151116. $10.1080 / 23311975.2016 .1151116$
Thomé, A.M.T., Scavarda, L.F., Scavarda, A. and Thomé, F.E.SdeS. (2016a), "Similarities and contrasts of complexity, uncertainty, risks, and resilience in supply chains and temporary multiorganization projects", International Journal of Project Management, Vol. 34 No. 7, pp. 1328-1346. 10.1016/j.ijproman.2015.10.012

Thomé, A.M.T., Scavarda, L.F. and Scavarda, A.J. (2016b), "Conducting systematic literature review in operations management", Production Planning \& Control, Vol. 27 No. 5, pp. 408-420. 10.1080/09537287.2015.1129464

Torp, O. and Klakegg, O. (2016), "Challenges in cost estimation under Uncertainty-A case study of the Decommissioning of Barsebäck nuclear power plant", Administrative Sciences, Vol. 6 No. 4, p. 14. 10.3390/admsci6040014

Tranfield, D., Denyer, D. and Smart, P. (2003), “Towards a methodology for developing evidenceinformed management knowledge by means of systematic review", British Journal of Management, Vol. 14 No. 3, pp. 207-222. 10.1111/14678551.00375

Transport Xtra. (2018), "IN DEPTH: Academics clash on causes of transport cost overruns [WWW Document]. Transport Xtra News", available at: https:// www.transportxtra.com/publications/local-transporttoday/news/56703/in-depth-academics-clash-oncauses-of-transport-cost-overruns./ [accessed Feb 24, 2019].

Tsai, T.-H. (2016), “A similarity-based Selfevolutionary model for Railway passenger arrival forecasting", Asian Transport Studies, Vol. 4, pp. $140-158$.

UK NAO. (2015), Major projects report 2014 and the equipment plan 2014 to 2015 (NO. HC 941-I), Ministry of defence: major projects report 2014 and the equipment plan 2014 to 2024. UK: National Audit Office.

UK NAO. (2018), Developing new care models through NHS vanguards (NO. HC 119). UK: Comptroller and Auditor General, UK National Audit Office.

US National Research Council. (2005), The Owner's Role in Project Risk Management, DEAM0199P08006. Washington, D.C: The National Academies Press.

Van Wee, B. (2007), "Rail Infrastructure: Challenges for Cost-Benefit Analysis and Other ex ante Evaluations", Transportation Planning and Technology, Vol. 30 No. 1, pp. 31-48. 10.1080/03081060701207995

Engineering Project Organization Journal

(C) 2021 Engineering Project Organization Society www.epossociety.org 
Vikingur Fridgeirsson, T. (2017), "Reference class forecasting in Icelandic transport infrastructure projects", Transport Problems No., Vol. 11 No. 2, pp. 103-115. 10.20858/tp.2016.11.2.10

von Branconi, C. and Loch, C.H. (2004), "Contracting for major projects: eight business levers for top management", International Journal of Project Management, Vol. 22 No. 2, pp. 119-130. 10.1016/ S0263-7863(03)00014-0

Walczak, R. and Majchrzak, T. (2018), "Implementation of the reference class forecasting method for projects implemented in a chemical industry company", Acta Oeconomica Pragensia, Vol. 26 No. 1, pp. 25-33. 10.18267/j.aop.593

Wan, X.Y., Wang, G.Q., Yi, P. and Bao, W.M. (2010), "Similarity-Based optimal operation of water and sediment in a Sediment-Laden reservoir", $W a$ ter Resources Management, Vol. 24 No. 15, pp. 4381-4402. 10.1007/s11269-010-9664-2

Whitney, K.M. and Daniels, C.B. (2013), "The root cause of failure in complex it projects: complexity itself", Procedia Computer Science, Vol. 20 No. 2, pp. 325-330. 10.1016/j.procs.2013.09.280

Williams, T. (2005), "Assessing and moving on from the dominant project management discourse in the light of project Overruns", IEEE Transactions on Engineering Management, Vol. 52 No. 4, pp. 497-508. 10.1109/TEM.2005.856572

Williams, T. (2017), "The nature of risk in complex projects", Project Management Journal, Vol. 48 No. 4, pp. 55-66. 10.1177/875697281704800405

Williams, T., Klakegg, O.J., Walker, D.H.T., Andersen, B. Magnussen, O.M., Jonny Klakegg, O. and Morten Magnussen, O. (2012), "Identifying and acting on early warning signs in complex projects", Project Management Journal, Vol. 43 No. 2, pp. 37-53. 10.1002/pmj.21259

Winch, G.M. and Maytorena, E. (2011), Managing Risk and Uncertainty on Projects. Oxford, UK: The Oxford Handbook of Project Management.

Yu, C.-P., Chen, H.-G., Klein, G. and Jiang, R. (2015), "The roots of executive information system development risks", Information and Software Technology, Vol. 68 No. 3, pp. 34-44. 10.1016/j. infsof.2015.08.001

Zheng, X., Le, Y., Chan, A.P.C., Hu, Y. and Li, Y. (2016), "Review of the application of social network analysis (SNA) in construction project management research", International Journal of Project Management, Vol. 34 No. 7, pp. 1214-1225. 10.1016/j. ijproman.2016.06.005 